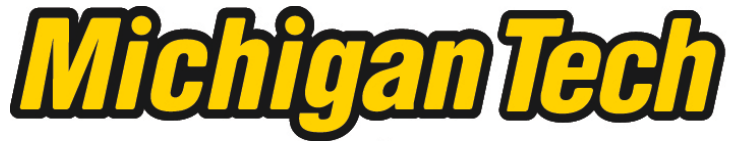 \\ Michigan Technological University Create the Future Digital Commons @ Michigan Tech
}

2014

\section{Age-Dependent Fragility and Life-Cycle Cost Analysis of Timber and Steel Distribution Poles Subjected to Hurricanes}

Abdullahi M. Salman

Michigan Technological University

Follow this and additional works at: https://digitalcommons.mtu.edu/etds

Part of the Civil Engineering Commons

Copyright 2014 Abdullahi M. Salman

\section{Recommended Citation}

Salman, Abdullahi M., "Age-Dependent Fragility and Life-Cycle Cost Analysis of Timber and Steel Distribution Poles Subjected to Hurricanes", Master's Thesis, Michigan Technological University, 2014.

https://doi.org/10.37099/mtu.dc.etds/776

Follow this and additional works at: https://digitalcommons.mtu.edu/etds

Part of the Civil Engineering Commons 
AGE-DEPENDENT FRAGILITY AND LIFE-CYCLE COST ANALYSIS OF TIMBER AND STEEL DISTRIBUTION POLES SUBJECTED TO HURRICANES

By

Abdullahi M. Salman

\begin{abstract}
A THESIS
Submitted in partial fulfillment of the requirements for the degree of MASTER OF SCIENCE

In Civil Engineering
\end{abstract}

MICHIGAN TECHNOLOGICAL UNIVERSITY

2014

(C) 2014 Abdullahi M. Salman 
This thesis has been approved in partial fulfillment of the requirements for the Degree of MASTER OF SCIENCE in Civil Engineering.

Department of Civil and Environmental Engineering

\author{
Thesis Advisor: $\quad$ Dr. Yue $\mathrm{Li}$
}

Committee Member:

Dr. William M. Bulleit

Committee Member:

Dr. Chee-Wooi Ten

Department Chair: $\quad$ Dr. David Hand 
To my Late Father. 


\section{Table of Contents}

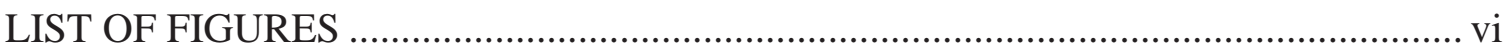

LIST OF TABLES ............................................................................................. vii

ACKNOWLEDGEMENTS ...................................................................................... vii

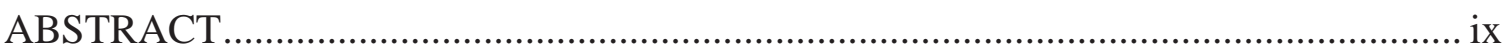

CHAPTER 1 INTRODUCTION ……………………...................................... 10

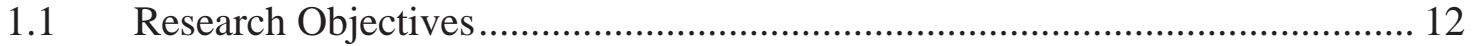

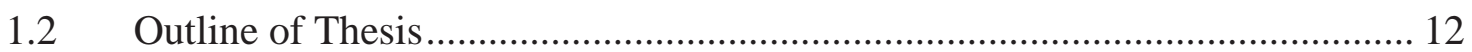

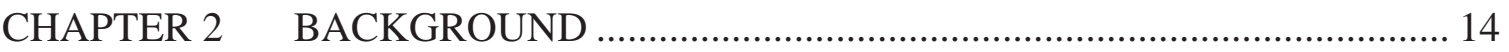

$2.1 \quad$ Power Distribution Systems.................................................................... 14

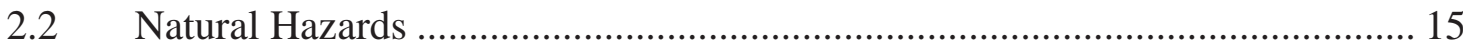

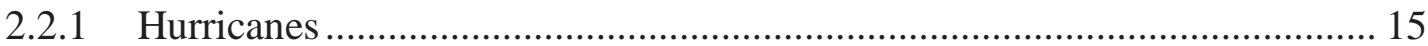

2.2.2 Earthquakes...................................................................................... 16

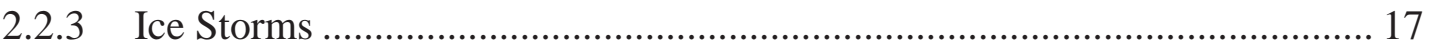

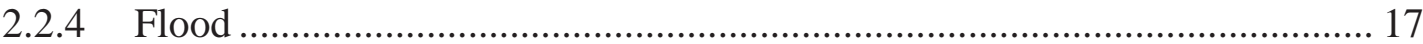

2.3 Historical Damage to Power Distribution Systems Due to Natural Hazards.... 18

2.4 Multi-dimensional Assessment of Power Systems ........................................... 20

2.4.1 Hazard Scenario Model.......................................................................... 20

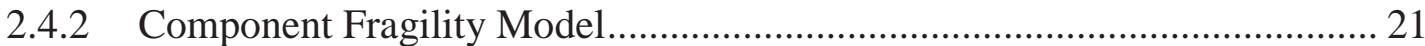

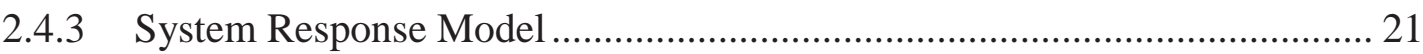

2.4.4 Restoration Model........................................................................... 22

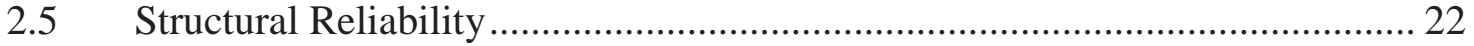

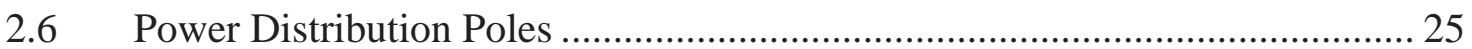




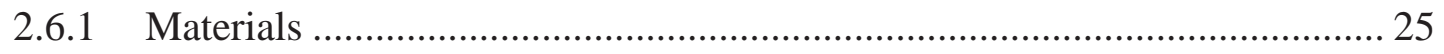

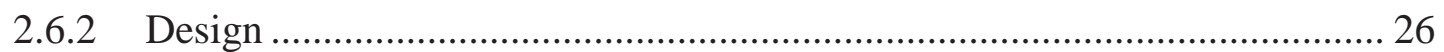

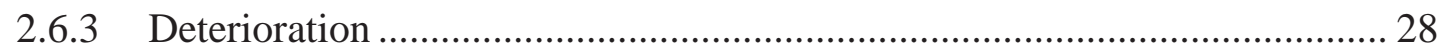

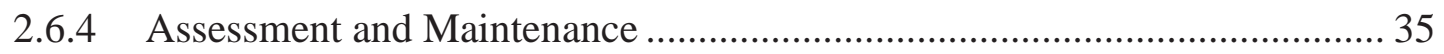

CHAPTER 3 FRAGILITY ANALYSIS OF STEEL AND TIMBER POLES............ 36

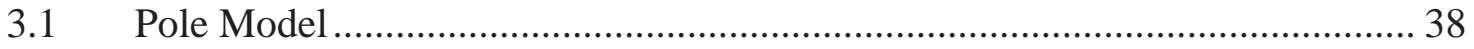

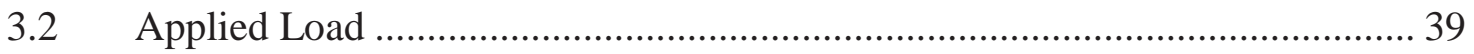

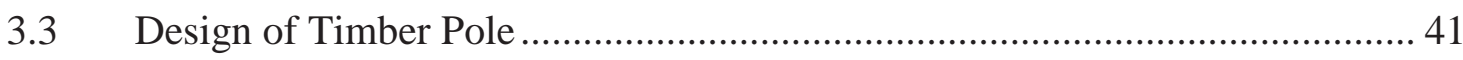

3.4 Design of Steel Pole .................................................................................. 42

3.5 Risk Assessment .................................................................................. 45

3.5.1 Fragility Analysis ................................................................................ 45

3.5.2 Annual Probability of Failure ................................................................... 47

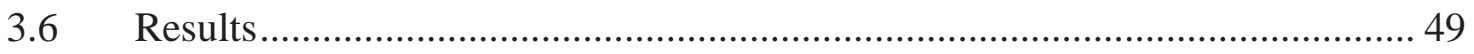

CHAPTER 4 LIFE-CYCLE COST ANALYSIS OF STEEL AND TIMBER POLES 56

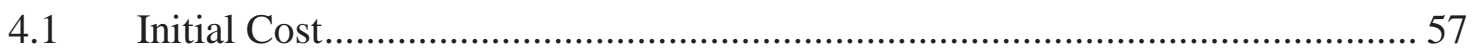

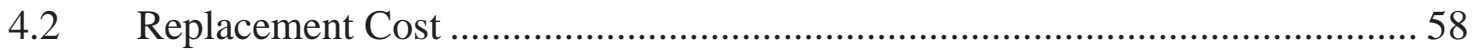

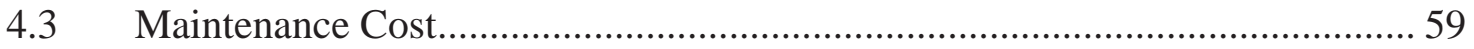

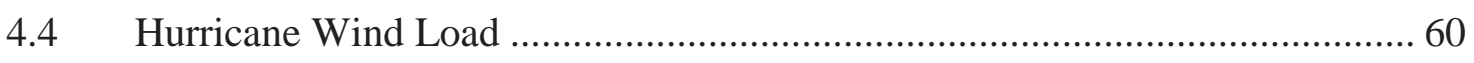

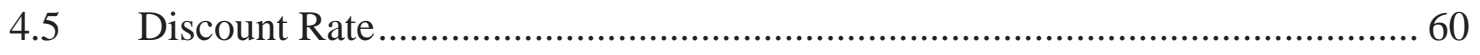

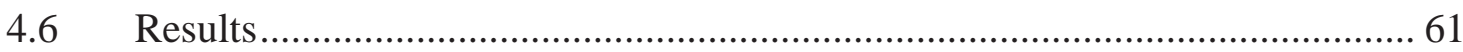

CHAPTER 5 FUTURE WORK RECOMMENDATIONS ……………………….... 65

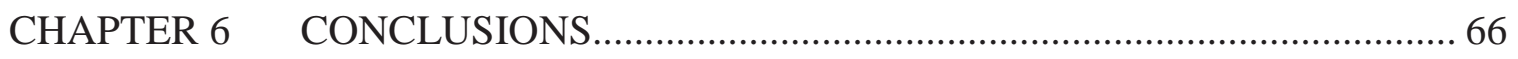

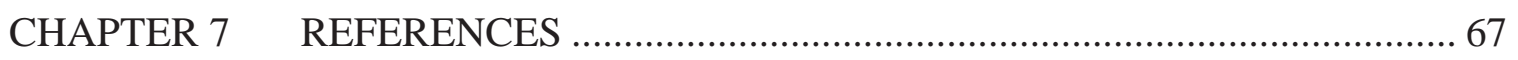




\section{LIST OF FIGURES}

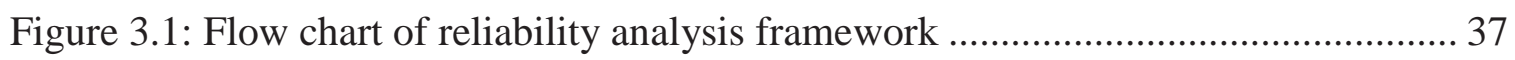

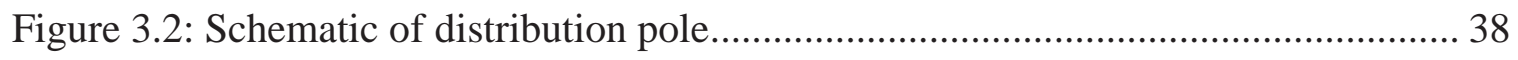

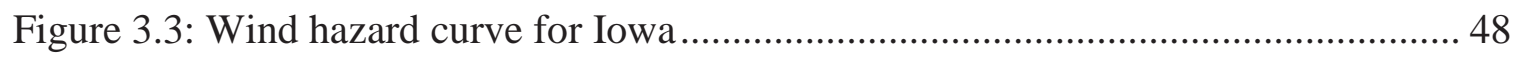

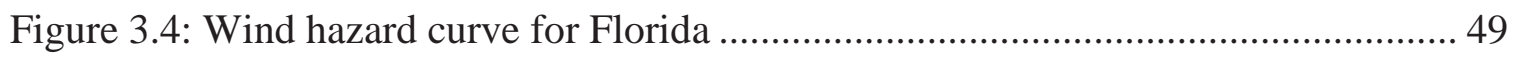

Figure 3.5: Percentage of strength remaining over time ........................................... 50

Figure 3.6: Fragility curve of new timber and steel poles .................................... 51

Figure 3.7: Fragility curves of timber and steel poles at 20 years ............................... 52

Figure 3.8: Fragility curves of timber and steel poles at 40 years ................................ 52

Figure 3.9: Fragility curves of timber and steel poles at 60 years ............................... 53

Figure 3.10: Annual probabilities of failure for poles located in Iowa.......................... 54

Figure 3.11: Annual probabilities of failure for poles located at the southern end of

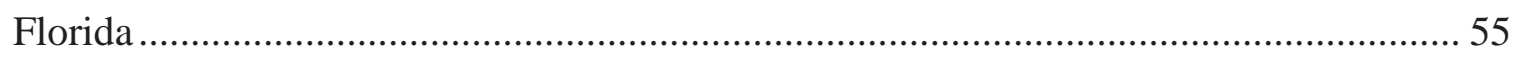

Figure 4.1: Present value of life-cycle cost for poles located in Iowa ........................... 62

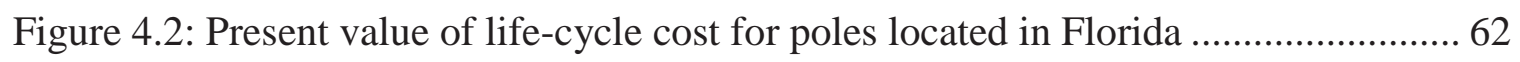

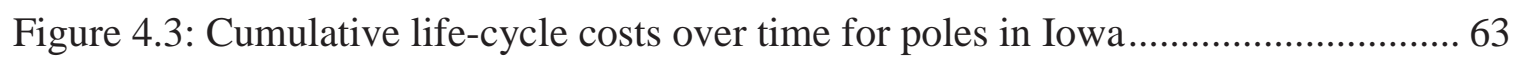

Figure 4.4: Cumulative life-cycle costs over time for poles in Florida .......................... 64 


\section{LIST OF TABLES}

Table 2.1: Historic hurricanes resulting in power outages ....................................... 18

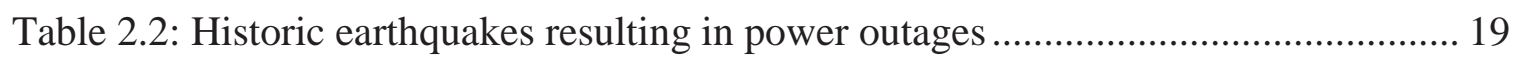

Table 2.3: Historic ice storms resulting in power outages....................................... 19

Table 2.4: Minimum average coating thickness grade (ASTM-A123, 2013) ................ 26

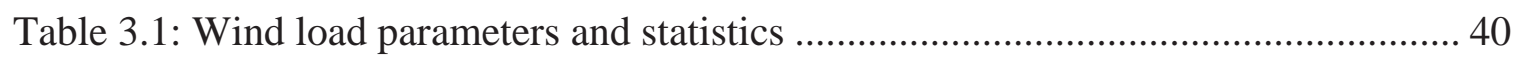

Table 3.2: Timber pole parameters and statistics.................................................... 41

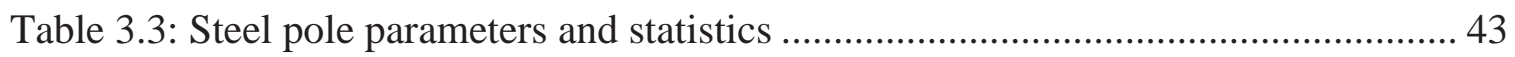

Table 3.4: Corrosion rates of zinc coating (AS/NZS-2041, 1998) ............................... 44

Table 3.5: Annual probabilities of failure for poles located in Iowa .............................. 53

Table 3.6: Annual probabilities of failure for poles located at the southern end of Florida

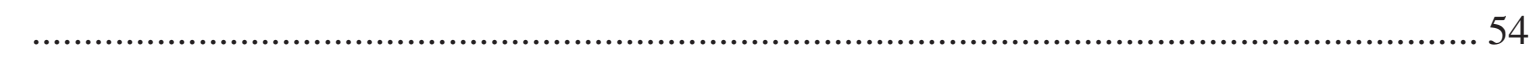

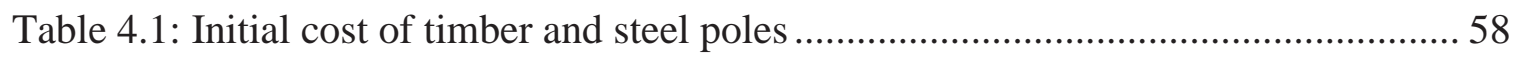

Table 4.2: Replacement cost of timber and steel poles............................................. 59

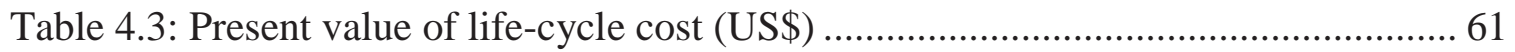




\section{ACKNOWLEDGEMENTS}

This thesis would not have been possible without the guidance and help of several individuals who in one way or another contributed and extended their valuable assistance in the preparation and completion of this study.

First of all, I would like to express my heart-felt gratitude to my supervisor and mentor, Dr. Yue Li for his guidance, advice, encouragement, and friendship during the course of this research.

I would like to express my gratitude to Dr. William M. Bulleit and Dr. Chee-Wooi Ten, who served as my graduate advisory committee members, for their time and assistance during the course of this research.

I owe my deepest gratitude to my parents, my uncle Engr. Lawal Audi, and my aunts Dr. Amina Odidi and Hajiya Hadiza Audi. Their love, support, and guidance made me the person I am today. Lastly, I will like to thank my siblings for their unwavering love and encouragement. 


\begin{abstract}
Power distribution systems are susceptible to extreme damage from natural hazards especially hurricanes. Hurricane winds can knock down distribution poles thereby causing damage to the system and power outages which can result in millions of dollars in lost revenue and restoration costs. Timber has been the dominant material used to support overhead lines in distribution systems. Recently however, utility companies have been searching for a cost-effective alternative to timber poles due to environmental concerns, durability, high cost of maintenance and need for improved aesthetics. Steel has emerged as a viable alternative to timber due to its advantages such as relatively lower maintenance cost, light weight, consistent performance, and invulnerability to wood-pecker attacks. Both timber and steel poles are prone to deterioration over time due to decay in the timber and corrosion of the steel. This research proposes a framework for conducting fragility analysis of timber and steel poles subjected to hurricane winds considering deterioration of the poles over time. Monte Carlo simulation was used to develop the fragility curves considering uncertainties in strength, geometry and wind loads. A framework for life-cycle cost analysis is also proposed to compare the steel and timber poles. The results show that steel poles can have superior reliability and lower life-cycle cost compared to timber poles, which makes them suitable substitutes.
\end{abstract}




\section{CHAPTER 1 INTRODUCTION}

Continuous supply of electricity is essential for the welfare, economy, and security of societies. In the event of natural disasters, continuous supply of electricity is essential not only to critical buildings such as hospitals and fire stations, but to the public as a whole. Consequently, the reliability of the power system is important. The power system is normally divided into generation, transmission and distribution sub-systems, and the reliability of all three systems should be considered. However, when it comes to failure due to natural hazards, the distribution system is the most vulnerable (Davidson et al., 2003).

Natural hazards that threaten the power system include hurricanes, earthquakes, floods, severe thunderstorms, and tornadoes. Each of these hazards causes failure in a different way and to different parts of the power system. The distribution system is mostly affected by hurricanes which can uproot distribution poles and damage distribution lines due to flying debris or falling trees. Recently in 2012 for example, hurricane Sandy caused severe damage to distribution systems in several coastal states causing over 8.5 million customers to lose power for weeks and even months in some areas (Blake et al., 2013).

Distribution poles act as support structures for the distribution lines and are mostly timber poles (Gustavsen \& Rolfseng, 2000). In recent years however, utility companies have been searching for cost-effective alternatives to timber poles due to environmental concerns, durability, high cost of maintenance, and need for improved aesthetics (Lacoursiere, 1999).

In research by Mankowski et al. (2002), 261 North American utility companies were surveyed. 116 of the companies reported that they had employed steel poles as substitutes for timber poles within 5 years before the survey. Other materials such as fiberglass, 
concrete, and laminated poles were also reported to have been used by some companies. Steel however, was the most commonly used substitute.

Steel poles have several advantages over timber poles, including reduced maintenance cost, predictability of behavior, consistent performance, insusceptible to wood-pecker attacks, light weight, factory pre-drilling is possible, environmentally friendly (recyclable, no toxic preservatives, no disposal concerns), and superior life-cycle cost (Lacoursiere, 1999).

A paper by George and Stetson (1999) discussed the use of steel poles for the construction of a $69 \mathrm{kV}$ single pole line in Central Nebraska. Steel poles were initially considered to extend the life of the distribution line and were later discovered to be cheaper than using timber poles. The authors also concluded that the steel poles have better bending capacity and weigh $50 \%$ less than timber poles.

The strength of both timber and steel poles deteriorates with time which reduces their reliabilities and makes them more susceptible to damage. For timber poles, the reduction of strength is mainly due to decay caused by fungi at areas where the pole is in contact with the ground. Strength of steel poles however deteriorates due to corrosion of the steel at or below the ground level caused by moisture and other chemicals in the soil. Both decay and corrosion reduce the strength of the poles by reducing their cross-sectional areas.

Little research has been done to investigate the advantages of using steel poles in place of timber poles to minimize the damage to the distribution system when subjected to natural hazards especially as the system ages. As utility companies increasingly adopt the use of steel poles, there is a need to look at their long-term structural behavior and effectiveness in terms of cost and how it compares to timber poles.

This research develops a framework to compare timber and steel poles subjected to natural hazards using structural reliability and life-cycle cost analysis while taking into 
account the deterioration in strength over time. To demonstrate this framework, two distribution poles (timber and steel) are designed making sure they have the same initial reliability. Fragility curves are then developed for the poles when subjected to high wind loads such as those experienced during hurricanes. The fragility curves are used to compare the reduction in reliability for both poles over time.

Life-cycle cost analysis is also performed to investigate how steel poles compare to timber poles. This is crucial for utility companies as they weigh the use of alternative materials and make decisions for future investment.

\subsection{Research Objectives}

The objectives of this research include:

Perform fragility analysis of timber and steel poles subjected to hurricane load and consider strength deterioration over time.

Perform a life-cycle cost analysis of timber and steel distribution poles.

$>$ Compare the performance of timber and steel poles over time based on the results from the fragility analysis and cost analysis.

\subsection{Outline of Thesis}

Chapter 2 provides a detailed literature review of the power distribution system, the natural hazards that affect the system and historic damage, and how distribution poles are designed. The chapter also reviews reliability theory and how it can be applied to the power system and finally, the various deterioration models in the literature are examined. 
Chapter 3 contains a framework for the fragility analysis of poles. The pole model used, the load considered and the procedures for conducting fragility analysis are also described. The results of the fragility analysis are presented and discussed.

Chapter 4 focuses on life-cycle analysis of steel and timber poles. The various costs associated with the poles and the hurricane loads considered for the analysis are described. The life-cycle analysis results are also presented and discussed.

Chapter 5 presents conclusions that can be drawn from the analysis results.

Chapter 6 provides some recommendations for future research in the comparative analysis of poles.

Chapter 7 details the references consulted during the course of this research. 


\section{CHAPTER 2}

\section{BACKGROUND}

\subsection{Power Distribution Systems}

The electric power system can be broadly divided into three subsystems: generation, transmission, and distribution. The generation plants produce electricity by using fossil fuels, nuclear energy, or renewable sources of energy. The power is then transported in bulk using the transmission system that uses wires supported by steel towers that are about $150 \mathrm{ft}$. high and spaced about $800 \mathrm{ft}$. apart (Willis \& Philipson, 2005). The voltage levels for the transmission system ranges from $34.5 \mathrm{kV}$ to as high as $1100 \mathrm{kV}$ in the US (Brown, 2008).

The distribution system transports and delivers power to the consumers after the voltage has been stepped down to the appropriate level. The distribution system uses wires that are carried by timber, steel or concrete poles that are 30 to $60 \mathrm{ft}$. high and spaced 100 to $150 \mathrm{ft}$. in the suburbs and 300 to $400 \mathrm{ft}$. in rural areas (Short, 2006). The voltage is usually between $4.16 \mathrm{kV}$ to $34.5 \mathrm{kV}$ in the primary distribution system (Brown, 2008).

Considering failure due to natural hazards, the distribution system is the most vulnerable (Davidson et al., 2003). This is because the generation stations are few and are usually designed to withstand high wind, floods, and earthquakes. The transmission system (towers and lines) is also designed to withstand natural hazards better than the distribution system. Another reason is that unlike the distribution system, there is always redundancy in the transmission system, i.e. there is always more than one way to transport the electricity from the generation plants.

The distribution system has several subsystems that include distribution substations, the primary distribution system, and the secondary distribution system. Distribution substations are the first stage in the distribution process. Electricity from the transmission system enters into a substation through a single transmission line. The main function of 
the substation is to step down the voltage to the distribution level. This is achieved by utilizing a transformer.

The primary distribution system is where the stepped-down power from the substation is carried to distribution transformers through feeders. The feeders exit the substation through underground feeder get-away which is routed to nearby poles. The cables then exit from the ground and become overhead three-phase main lines.

Overhead feeder components include poles, overhead lines, and pole-mounted transformers. Poles support the overhead distribution equipment and timber is the most commonly used material. Concrete and steel poles are also available.

Distribution poles and lines are critical in the reliability of a distribution system during natural hazards because they are exposed to falling trees and other debris, as well as direct wind forces.

The secondary distribution system is the last stage where the stepped-down electricity from the pole-mounted transformers is transported to the consumers. This is done through simple overhead service drops or more complex secondary networks. Secondary systems are usually radial (only one path available) except for vital structures that are essential during disasters (hospitals for example).

\subsection{Natural Hazards}

\subsubsection{Hurricanes}

A hurricane is one of the types of tropical cyclones and it is an intense weather system with a well-defined circulation and wind speeds exceeding $74 \mathrm{mph}$. All Atlantic and Gulf coastal areas of the US are prone to hurricanes. On average, the US coastline is hit by five hurricanes in a typical 3-year period (NWS, 2001). Hurricanes reaching Category 3 
on the Saffir-Simpson scale are considered major hurricanes, and they can cause considerable damage to the power system.

Hurricanes rarely affect power generation stations and cause little to moderate damage to the transmission system. This is because generation and transmission systems are designed to withstand high wind loads. The distribution system however can be significantly affected by hurricanes. Much of the damage to the distribution system is done by high winds that can uproot distribution poles and damage distribution lines due to flying debris or falling trees.

\subsubsection{Earthquakes}

Most areas in the US have some seismic risk with certain areas being more prone than others. Earthquakes can cause damage to power generation facilities depending on the intensity of the earthquake and size of the power plant. Most power plants are usually designed to have good seismic resistance. Transmission towers are rarely damaged by the actual shaking of the ground during earthquakes. This is because the towers are designed for severe loads such as combined wind and ice, and extra loads due to collapse of adjacent towers. Instead, damage is mostly due to foundation failures caused by landslides, ground fracture and liquefaction.

Earthquakes usually cause little damage to distribution system components because of the sizes and nature of these components. Timber poles for example are more flexible than steel transmission towers and this consequently reduces the seismic stress they experience. 


\subsubsection{Ice Storms}

An ice storm is an extreme weather event that occurs when cold rain freezes after coming in contact with objects such as power lines and forms a layer of ice. The ice builds up on the power lines and transmission towers thereby placing heavy loads on these components. The ice buildup also increases the projected wind area for these structures and consequently increases the wind loads.

\subsubsection{Flood}

Tropical cyclones usually lead to torrential rains that can cause widespread and destructive floods. These floods can cause considerable damage to power systems, even those that are well inland. Power generation plants can be flooded and falling trees can damage the distribution lines and poles. Large amount of water can also soften soils and threaten the foundation of transmission towers.

The most damaging natural hazard to the power system is hurricane and the most vulnerable part of the system is the distribution system. This is why this research focused on hurricanes and distribution systems. 


\subsection{Historical Damage to Power Distribution Systems Due to Natural Hazards}

Table 2.1: Historic hurricanes resulting in power outages

\begin{tabular}{|c|c|c|c|c|c|c|}
\hline $\mathrm{S} / \mathrm{N}$ & Hurricane & Year & Areas Affected & Damage & $\begin{array}{l}\text { Duration of } \\
\text { Outages }\end{array}$ & $\begin{array}{l}\text { Total } \\
\text { Economic } \\
\text { Loss }\end{array}$ \\
\hline 1 & $\begin{array}{l}\text { Hurricane } \\
\text { Sandy }\end{array}$ & 2012 & 21 states affected. & $\begin{array}{l}8.5 \text { million people lost } \\
\text { power. }\end{array}$ & $\begin{array}{l}\text { Several } \\
\text { weeks and } \\
\text { months in } \\
\text { some areas. }\end{array}$ & $\begin{array}{l}\text { Over } \$ 50 \\
\text { billion } \\
\text { (prelim) }\end{array}$ \\
\hline 2 & $\begin{array}{l}\text { Hurricane } \\
\text { Isaac }\end{array}$ & 2012 & $\begin{array}{l}\text { Florida, Louisiana, } \\
\text { Mississippi, } \\
\text { Alabama. }\end{array}$ & $\begin{array}{l}113,000 \text { customers lost } \\
\text { power in Florida. } \\
47 \% \text { of customers lost } \\
\text { power in Louisiana. }\end{array}$ & Several days. & $\$ 2.35$ billion \\
\hline 3 & $\begin{array}{l}\text { Hurricane } \\
\text { Ike }\end{array}$ & 2008 & $\begin{array}{l}\text { Florida, Texas, } \\
\text { Louisiana, Arkansas. }\end{array}$ & $\begin{array}{l}2.6 \text { million people lost } \\
\text { power in Texas and } \\
\text { Louisiana. } 2.6 \text { million also } \\
\text { lost power in the Ohio } \\
\text { Valley. }\end{array}$ & Up to a week. & $\$ 24.9$ billion \\
\hline 4 & $\begin{array}{l}\text { Hurricane } \\
\text { Katrina }\end{array}$ & 2005 & 12 states affected. & $\begin{array}{l}2.6 \text { million customers lost } \\
\text { power. }\end{array}$ & $\begin{array}{l}\text { Up to } 6 \\
\text { weeks. }\end{array}$ & $\$ 108$ billion \\
\hline 5 & $\begin{array}{l}\text { Hurricane } \\
\text { Rita }\end{array}$ & 2005 & $\begin{array}{l}\text { Arkansas, Florida, } \\
\text { Louisiana, Texas, } \\
\text { Mississippi, } \\
\text { Missouri. }\end{array}$ & $\begin{array}{l}500,000 \text { people without } \\
\text { power in Louisiana. } \\
1.5 \text { million People without } \\
\text { power in Texas. }\end{array}$ & Up to weeks. & $\begin{array}{l}\$ 12.037 \\
\text { billion }\end{array}$ \\
\hline 6 & $\begin{array}{l}\text { Hurricane } \\
\text { Wilma }\end{array}$ & 2005 & Florida & $\begin{array}{l}\text { Over } 3.5 \text { million people } \\
\text { lost power in Florida. }\end{array}$ & $\begin{array}{l}\text { Up to } 3 \\
\text { weeks. }\end{array}$ & $\$ 20.6$ billion \\
\hline 7 & $\begin{array}{l}\text { Hurricane } \\
\text { Cindy }\end{array}$ & 2005 & $\begin{array}{l}\text { Louisiana, Alabama, } \\
\text { Georgia. }\end{array}$ & $\begin{array}{l}278,000 \text { lost power in } \\
\text { Louisiana. }\end{array}$ & Several days. & $\$ 320$ million \\
\hline 8 & $\begin{array}{l}\text { Hurricane } \\
\text { Ivan }\end{array}$ & 2004 & $\begin{array}{l}\text { Florida, Alabama, } \\
\text { Mississippi, } \\
\text { Louisiana, Georgia, } \\
\text { Tennessee, North } \\
\text { Carolina. }\end{array}$ & $\begin{array}{l}\text { Over } 1.8 \text { million lost power } \\
\text { in the affected states. }\end{array}$ & - & $\$ 14.2$ billion \\
\hline 9 & $\begin{array}{l}\text { Hurricane } \\
\text { Irene }\end{array}$ & 1999 & Florida. & $\begin{array}{l}\text { Over } 4 \text { million customers } \\
\text { lost power. }\end{array}$ & $\begin{array}{l}\text { Several } \\
\text { weeks. }\end{array}$ & $\begin{array}{l}\$ 8.6 \text { billion } \\
\text { due to } \\
\text { flooding. }\end{array}$ \\
\hline 10 & $\begin{array}{l}\text { Hurricane } \\
\text { Andrew }\end{array}$ & 1992 & $\begin{array}{l}\text { Florida, Southern } \\
\text { US. }\end{array}$ & $\begin{array}{l}1.4 \text { million }(44 \%) \text { of } \\
\text { Florida Power and Light } \\
\text { Company customers lost } \\
\text { power. }\end{array}$ & - & $\$ 26.5$ billion \\
\hline 11 & $\begin{array}{l}\text { Hurricane } \\
\text { Gloria }\end{array}$ & 1985 & $\begin{array}{l}\text { New Jersey, Long } \\
\text { Island, New } \\
\text { England, North } \\
\text { Carolina. }\end{array}$ & $\begin{array}{l}\text { Over } 4 \text { million customers } \\
\text { lost power. }\end{array}$ & $\begin{array}{l}\text { Up to } 2 \\
\text { weeks. }\end{array}$ & $\$ 900$ million \\
\hline
\end{tabular}


Table 2.2: Historic earthquakes resulting in power outages

\begin{tabular}{|c|c|c|c|c|c|c|}
\hline $\mathrm{S} / \mathrm{N}$ & Earthquake & Year & $\begin{array}{l}\text { Areas } \\
\text { Affected }\end{array}$ & Damage & $\begin{array}{l}\text { Duration of } \\
\text { Outages }\end{array}$ & $\begin{array}{l}\text { Total } \\
\text { Economic } \\
\text { Loss }\end{array}$ \\
\hline 1 & $\begin{array}{l}\text { Tohoku } \\
\text { earthquake }\end{array}$ & 2011 & Japan & 4.4 million lost power. & - & $\$ 235$ billion \\
\hline 2 & $\begin{array}{l}\text { Eureka } \\
\text { earthquake }\end{array}$ & 2010 & California & 28,000 lost power. & Hours & $\$ 43$ million \\
\hline 3 & $\begin{array}{l}\text { Hawaii } \\
\text { earthquake }\end{array}$ & 2006 & Hawaii & - & Hours & $\begin{array}{l}\text { Over } \$ 200 \\
\text { million }\end{array}$ \\
\hline 4 & $\begin{array}{l}\text { Nisqually } \\
\text { Earthquake }\end{array}$ & 2001 & $\begin{array}{l}\text { Washington } \\
\text { State }\end{array}$ & 17,000 lost power. & 1 day & $\$ 2$ billion \\
\hline 5 & $\begin{array}{l}\text { Northridge } \\
\text { earthquake }\end{array}$ & 1994 & California & $\begin{array}{l}\text { Over } 680,000 \text { customers } \\
\text { lost power. }\end{array}$ & Up to a week & $\begin{array}{l}\text { Over } \$ 20 \\
\text { billion }\end{array}$ \\
\hline 6 & $\begin{array}{l}\text { Loma } \\
\text { Prieta } \\
\text { earthquake }\end{array}$ & 1989 & California & 1.4 million lost power & Hours & $\begin{array}{l}\text { Over } \$ 5.6 \\
\text { billion }\end{array}$ \\
\hline
\end{tabular}

Table 2.3: Historic ice storms resulting in power outages

\begin{tabular}{|c|c|c|c|c|c|c|}
\hline $\mathrm{S} / \mathrm{N}$ & Ice storm & Year & Areas Affected & Damage & $\begin{array}{l}\text { Duration of } \\
\text { Outages }\end{array}$ & $\begin{array}{l}\text { Total } \\
\text { Economic } \\
\text { Loss }\end{array}$ \\
\hline 1 & $\begin{array}{l}2009 \text { ice } \\
\text { storm }\end{array}$ & 2009 & $\begin{array}{l}\text { Northern } \\
\text { Arkansas to } \\
\text { Ohio valley }\end{array}$ & $\begin{array}{l}1.3 \text { million lost } \\
\text { power }\end{array}$ & $\begin{array}{l}\text { Up to } 10 \\
\text { days }\end{array}$ & - \\
\hline 2 & $\begin{array}{l}2005 \text { ice } \\
\text { storms }\end{array}$ & 2005 & $\begin{array}{l}\text { North Carolina, } \\
\text { Virginia, } \\
\text { Georgia, South } \\
\text { Carolina }\end{array}$ & $\begin{array}{l}600,000 \text { lost } \\
\text { power }\end{array}$ & $\begin{array}{l}\text { Up to a } \\
\text { week }\end{array}$ & - \\
\hline 3 & $\begin{array}{l}2002 \text { Central } \\
\text { plains ice } \\
\text { storm }\end{array}$ & 2002 & $\begin{array}{l}\text { Mid-west } \\
\text { especially } \\
\text { Kansas } \\
\end{array}$ & $\begin{array}{l}650,000 \text { lost } \\
\text { power }\end{array}$ & $\begin{array}{l}\text { Up to } 14 \\
\text { days }\end{array}$ & - \\
\hline 4 & $\begin{array}{l}1998 \text { North } \\
\text { American ice } \\
\text { storm }\end{array}$ & 1998 & $\begin{array}{l}\text { Canada and } \\
\text { northeastern US }\end{array}$ & $\begin{array}{l}\text { Up to } 4 \text { million } \\
\text { lost power }\end{array}$ & - & $\begin{array}{l}\$ 4 \text { to } \$ 6 \\
\text { billion }\end{array}$ \\
\hline
\end{tabular}

Sources: National Hurricane Center, US Department of Energy;

Office of Electricity Delivery and Energy Reliability, US Department of Energy;

National Oceanic and Atmospheric Administration 


\subsection{Multi-dimensional Assessment of Power Systems}

To fully describe the reliability and resilience of power systems, a comprehensive multidimensional assessment is required. Ouyang and Dueñas-Osorio (2014) defined resilience as "the joint ability of distributed systems, such as electric power systems, to resist (prevent and withstand) multiple possible hazards, absorb the initial damage, and recover to normal operation."

The time-dependent resilience of a power system can be divided into 3 distinct time intervals that include disaster prevention, damage propagation, and assessment and recovery.

A comprehensive multi-dimensional assessment of power systems consists of four interrelated models; hazard scenario model, component fragility model, response model, and a restoration model (Ouyang \& Dueñas-Osorio, 2014).

\subsubsection{Hazard Scenario Model}

This model aims to describe the occurrence of hazards such as hurricanes using a probabilistic modeling approach. Russell and Schueller (1974) investigated the occurrence of hurricanes in the Texas Gulf coast region and concluded that a Poisson

process can be used to model the occurrence of hurricanes. Ouyang and Dueñas-Osorio (2014) and Wen and Kang (2001) also suggested using the Poisson process for modeling the occurrence of hurricanes and earthquakes. 


\subsubsection{Component Fragility Model}

This model involves calculating the conditional probability of failure of a single power system component with the natural hazard loading parameter(s) as the conditioning variable (Han et. al. 2013). For practical purposes, only the most critical components of the system are usually considered. These may include transmission substations, transmission lines, distribution lines, and local distribution circuits. The fragility analysis of the components can be carried out using the concept of structural reliability which will be described later in this thesis.

Component fragility analysis is usually carried out independently for different failure modes by assuming that the modes are statistically independent. For example, a distribution pole can fail by fracture (flexural failure) or by the failure of the foundation. Calculating the probability of failure due to combination of modes requires considering the joint probabilities and is usually tedious.

\subsubsection{System Response Model}

This model describes the power system response after a component failure due to hazards. Several models have been developed for describing system response such as the AC-based power flow models, hidden failure models, stochastic models and so on. Based on these models, Ouyang and Dueñas-Osorio (2014) developed a system response model that assumes that a component failure alters the topology of a grid and divides it into different unconnected sub-grids. Each sub-grid is then analyzed according to certain set of rules developed based on consideration of factors such as the presence of a generating plant in a sub-grid and the capacity of the generating plant compared to the total demand within the sub-grid. 


\subsubsection{Restoration Model}

This model studies the restoration process of the power system after the occurrence of a certain hazard. An adequate model needs to take into account different damage states of the system and its components. Ouyang and Dueñas-Osorio (2014) developed a restoration model based on the emergency plan of a local utility company. The model considers two critical factors.

The first factor involves the mobilization of restoration resources. Here, resource quantities (repair crews, vehicles, equipment, and replacement components) and restoration times for different damage states are considered. The second factor considered is the restoration sequence. The proposed sequence is given below.

i. Repair transmission infrastructure (substations and lines).

ii. Repair primary distribution infrastructure that will restore power to greatest number of customers.

iii. Repair the secondary distribution system that delivers power from distribution nodes to individual customers.

\subsection{Structural Reliability}

Structural reliability is the application of probabilistic methods to study the safety of structures. The reliability of a structure refers to the probability that the structure will remain functional for a certain amount of defined time-period (Yao \& Kawamura, 2001). The concept of structural reliability was incorporated into design methods in the seventies in the form of Load and Resistance Factor Design (LRFD). The objective of structural design based on reliability theory is to reduce the probability of failure to a tolerable level. 
The basic concept of reliability theory can be explained with the equation below where the performance of a structure is described by a performance (limit state) function (Foschi, 2004).

$$
\begin{aligned}
& \mathrm{G}(\mathrm{x})=\mathrm{C}\left(\mathrm{x}_{\mathrm{c}}, \mathrm{d}_{\mathrm{c}}\right)-\mathrm{L}\left(\mathrm{x}_{\mathrm{L}}, \mathrm{d}_{\mathrm{L}}\right) \\
& \text { Where: } \quad \mathrm{G}(\mathrm{x})=\text { performance function } \\
& \mathrm{C}=\text { capacity } \\
& \mathrm{L}=\text { load } \\
& \mathrm{x}_{\mathrm{c}}=\text { uncertain parameters (variables) related to capacity } \\
& \mathrm{d}_{\mathrm{c}}=\text { deterministic parameters related to capacity } \\
& \mathrm{x}_{\mathrm{L}}=\text { uncertain parameters (variables) related to load } \\
& \mathrm{d}_{\mathrm{L}}=\text { deterministic parameters related to load }
\end{aligned}
$$

From the above equation, the probability of failure $\left(\mathrm{P}_{\mathrm{F}}\right)$ or non-performance of the structure is the probability that $\mathrm{G}<0$ (i.e., $\mathrm{L}>\mathrm{C}$ ). The reliability of the structure will then be the complement of the probability of failure, i.e., $1-\mathrm{P}_{\mathrm{F}}$.

To calculate the reliability of a structure or system, statistical information for all the random variables related to capacity and load are required. The variables related to capacity depends on the material used and can be estimated from test data. Variables related to load can be obtained from historical data such as maximum wind speeds, earthquake intensities, and so on. Data may not be available for the estimation of some variables in which case subjective estimates can be made and the effect of such assumptions on the reliability can be studied using sensitivity analysis.

A plot of the probabilities of failure against different values of the load is called a fragility curve. Fragility analysis is important in situations where loads on a structure are 
uncertain, or the capacity of the structure varies due to spatial or temporal variation in material strength, or in cases where a system is poorly understood.

Fragility analysis can be used to study the performance of a structure made with different material types so as to make informed decision on balancing between economy and safety. Fragility analysis can also be used to investigate the effectiveness of various retrofitting measures on structures. It can be used in performing cost-benefit analysis to assess the financial benefit of retrofit measures.

To estimate the probability of failure and subsequently the reliability, several methods can be used. The most common methods are Monte Carlo simulation, First-Order Reliability Method (FORM), and Second-Order Reliability Method (SORM).

Monte Carlo simulation is the easiest and most straightforward computer simulation method. It involves generating random numbers for the variables involved in a formulation. For the performance function $\mathrm{G}(\mathrm{x})$ above, random values of $\mathrm{x}$ can be generated and the function can then be evaluated. Since failure occurs when $G(x)<0$, the sign of the results can be checked and failure events identified. If the total number of values of $\mathrm{x}$ is $\mathrm{N}$, and $\mathrm{N}_{\mathrm{f}}$ is the total failure events, the probability of failure is then given by

$$
P_{f}=\frac{N_{f}}{N}
$$

The accuracy of the method increases as the number of random values generated increases. For systems with very low probability of failure, a large number of random values is required which in turn increases simulation time and effort. Methods such as Importance Sampling or Adaptive Sampling Simulation can be used to overcome this short fall of Monte Carlo Simulation. 


\subsection{Power Distribution Poles}

\subsubsection{Materials}

\subsubsection{Timber}

Timber has been the material of choice for supporting power distribution lines for several decades. There are over 100 million timber poles in use across the United States (A. H. Stewart \& Goodman, 1990). The common species of timber used for poles in the US include southern pine, Douglas fir, and western red cedar with southern pine the most commonly used (Wolfe \& Moody, 1997). Timber poles have certain advantages such as low initial cost, natural insulation properties, and ease of transport (Shafieezadeh et al., 2014).

Strength of timber poles has been documented by the American National Standards Institute (ANSI-O5.1, 2002). This document provides the fiber stress of different species of timber based on extensive test data. ANSI-O5.1 (2002) divided the poles into ten classes with class 1 having the largest tip circumference and highest fiber stress.

Service life of timber poles have been a subject of much discussion. According to the NESC, timber poles should be replaced when their strength falls below $66 \%$ of the initial strength. Most utilities use 30 to 40 years as an estimated service life (Mankowski et al., 2002). However, some research and several surveys show that the service life of timber poles can range from 60 to 80 years depending on species, location, and maintenance (Morrell, 2008; A. J. Stewart, 1996).

\subsubsection{Steel}

In recent years, utility companies have been searching for cost-effective alternatives to timber poles due to environmental concerns, high cost of maintenance, and need for 
improved aesthetics (Lacoursiere, 1999). According to research by Mankowski et al. (2002), steel poles are the most frequently used substitute.

The type of metal used for most steel poles is hot-dipped galvanized steel (Zamanzadeh et al., 2006). This is a type of steel that has been coated with zinc to reduce corrosion. Zinc has the ability of protecting steel from corrosion in moderately corrosive soils by acting as a galvanic (sacrificial) metal.

The base metal used for steel poles is usually 11-gauge sheet steel (Bolin \& Smith, 2011). The steel material conforms to the American Society for Testing and Materials (ASTM) specification A572-04. The minimum average coating thickness of the poles is governed by ASTM A123 and is shown in Table 2.4.

Table 2.4: Minimum average coating thickness grade (ASTM-A123, 2013)

\begin{tabular}{|c|c|c|c|c|c|}
\hline Material Category & \multicolumn{5}{|c|}{ All Specimens Tested Steel Thickness Range (Measured). } \\
\hline $\mathrm{mm}$. & $<1.6$ & 1.6 to 3.2 & 3.2 to 4.8 & 4.8 to 6.4 & $\geq 6.4$ \\
\hline inches. & $<1 / 16^{\prime \prime}$ & $1 / 16^{\prime \prime}$ to $1 / \mathrm{s}^{\prime \prime}$ & $1 / 8^{\prime \prime}$ to ${ }^{3} / 1{ }^{\prime \prime}$ & $3 / 16^{\prime \prime}$ to $1 / 4 "$ & $z^{1 / 4} 4^{n}$ \\
\hline Structural Shapes & 45 & 65 & 75 & 85 & 100 \\
\hline Strip and Bar & 45 & 65 & 75 & 85 & 100 \\
\hline Pipe and Tubing & 45 & 45 & 75 & 75 & 75 \\
\hline Wire & 35 & 50 & 60 & 65 & 80 \\
\hline Reinforcing Bar & & & & & 100 \\
\hline
\end{tabular}

\subsubsection{Design}

Currently, there are two methods for the design of utility distribution poles in the US. The first one is that developed by NESC (2002) which is based on load and strength factors selected based on engineering judgment and experience. In order to accommodate new materials and unforeseen applications (e.g., joint-usage of poles), the ASCE developed another method of design based on reliability-based criteria. This method is presented in Manual No.111 titled: "Reliability-Based Design of Utility Pole Structures”. 
This reliability-based design is applicable to poles made of any materials, thereby allowing companies to compare cost of using different poles. The design approach based on this manual will be followed in this research and is described below.

A distribution line is divided into two components: the structural support system (poles and foundation) and the wire system. These components are treated separately when it comes to design. The design of the structural support system is based on damage limit states, i.e., the design equations are provided to prevent damage of components from weather-related events.

The load and resistance factor design equations as specified in ASCE-111 (2006) are given below for different load events.

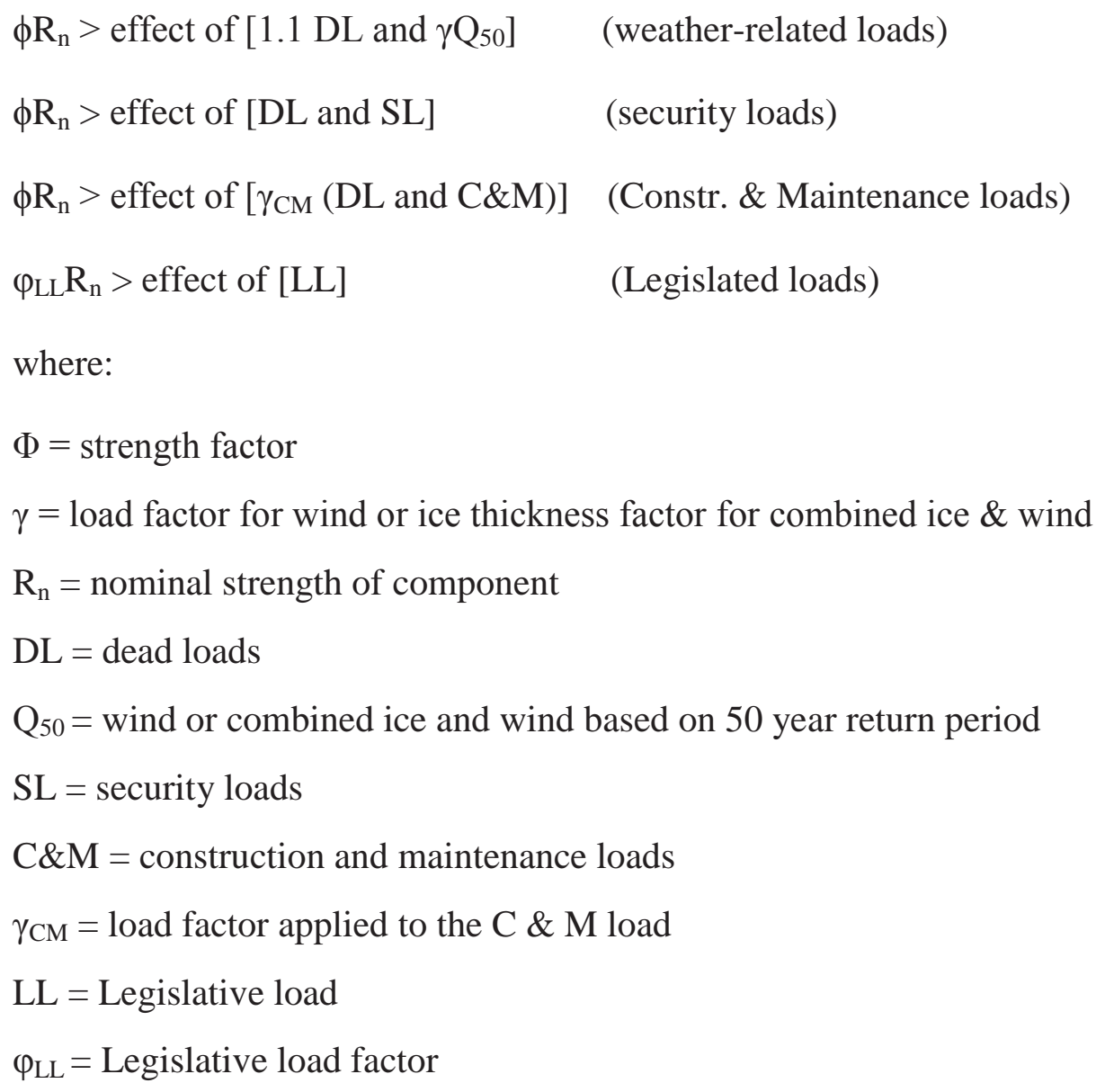


The strength of a distribution pole depends on several parameters, such as geometry, material type, support condition, and manufacturing process. These parameters introduce uncertainties in the strength of the pole. Therefore, the strength of the pole is a random variable that can be described by a probability density function (PDF).

The ASCE manual defines the nominal resistance of a pole $\left(R_{n}\right)$ as the strength that will be exceeded by $95 \%$ of the poles in a population (i.e., $5 \%$ lower exclusion limit (LEL)). Three methods are presented by the manual for estimating $\mathrm{R}_{\mathrm{n}}$ :

i. Empirical analysis based on test data;

ii. Mechanics-based models in conjunction with Monte Carlo simulation; and

iii. Default assignment of material distribution parameters.

\subsubsection{Deterioration}

\subsubsection{Timber Poles}

Timber poles are susceptible to decay due to fungal attack and are also vulnerable to attack by insects and woodpeckers. Decay usually occurs at the ground level or just below the ground. The rate of decay of timber depends on several factors such as timber species, climatic conditions (temperature, rainfall, and humidity), initial preservative treatment, and nature of fungal/insect attack. This means that any decay model can only be an approximation.

There are few models developed to estimate the rate of deterioration of timber poles. Some of these models are discussed below.

i. Yuan Li et al. (2005) developed a decay model based on field data from 13,940 poles ranging from age 1 to 79 years. The poles were from locations in Iowa where the 
soil is mostly silty loam which is rich and black. About $8 \%$ of these poles showed various degrees of decay. Non-destructive evaluation of residual strength was used, which entails removing external decay and assessing internal decay by drilling. This allows the evaluation of the effective area of the cross-section at the ground line.

A plot of the percentage of decayed poles at every age for the entire population showed that the age at which decay starts for most of the poles is 10 years. This is referred to as penetration age. The plot also shows that the percentage of decayed poles increases linearly with time starting at about 10 years. Using regression analysis, the authors developed the equation below to model the percentage of decayed poles as a function of time.

$$
\operatorname{Per}(t)=b_{1} t-b_{2}
$$

Where $\operatorname{Per}(\mathrm{t})$ is the percentage of decayed poles which is also the conditional probability that a pole at age $\mathrm{t}$ is decayed. Henceforth, Per(t) will be referred to as the Conditional Probability of Decay (CPD). The values of $b_{1}$ and $b_{2}$ where evaluated as 0.004 and 0.04 , respectively, from the regression analysis.

A plot of percentage of strength lost for the decayed poles of various ages indicates that the degradation trend is linear and can be represented with the equation below.

$$
L_{\text {spm }}(t)=a_{1} t-a_{2}
$$

where: $L_{s p m}(t)$ is the lost strength percentage mean at time $t$.

After removal of several outliers, the authors used regression analysis to find the values of $\mathrm{a}_{1}$ and $\mathrm{a}_{2}$ as 0.014418 and 0.10683 , respectively. The above equation however, only characterizes the loss of strength after decay has started.

Using the above 2 equations, Shafieezadeh et al. (2014) derived the following equation for the strength of timber poles at any time $t$. 


$$
R(t)=R_{o}\left[1-\left(a_{1} t-a_{2}\right)\left(b_{1} t-b_{2}\right)\right]
$$

where $\mathrm{R}_{\mathrm{o}}=$ initial strength.

It should be noted that the above equation only applies for $t$ greater than or equal to 10 years. If site specific information is available, the equation can be modified to account for poles with penetration time other than 10 years. For the purpose of this research however, 10 years will be used.

Shafieezadeh et al. (2014) also used the data from Yuan Li et al. (2005) to develop an equation for covariance of the capacity of timber poles as a function of time. The equation was used to plot the covariance of southern pine poles. The plot showed that as the poles ages, the uncertainty in the strength increases. The figure developed by Shafieezadeh et al. (2014) was used to obtain the covariance of the pole strength at different ages in this study.

ii. Wang and Leicester (2008) propose another model for in-ground timber attacked by decay fungi. The model is based on 3 field tests with the first test carried out between 1968 and 2004 on 77 untreated species of heartwood. The second test was on untreated species for 2.5 years while the last test was on 3 treated species in 38 locations within Australia.

The model assumes the decay follows an idealized bilinear relation over time and is characterized by two parameters: time lag before decay starts, and decay rate. The decay depth at a time $t$ is given by:

$$
d_{t}=\left\{\begin{array}{lr}
c t^{2} & \text { if } t \leq t_{d_{o}} \\
\left(t-t_{\text {lag }}\right) r & \text { if } t>t_{d_{o}}
\end{array}\right.
$$

where: $d_{t}=$ decay depth at time $t$,

$$
\mathrm{t}_{\mathrm{lag}}=\text { time lag before decay starts (yrs), }
$$


$\mathrm{d}_{\mathrm{o}}=$ decay threshold $=5 \mathrm{~mm}$ if no data is available,

$\mathrm{t}_{\mathrm{do}}=$ time in which decay reaches its threshold (yrs)

$\mathrm{r}=$ decay rate $(\mathrm{mm} / \mathrm{yr})$

$t_{d o}=t_{\text {lag }}+\frac{d_{o}}{r} \quad c=\frac{d_{o}}{t_{d o}^{2}}$

For untreated wood, $\quad r_{u n t}=k_{w} \times k_{c}$

where $\mathrm{k}_{\mathrm{w}}=$ wood parameter $(0.23$ to 1.36 for heartwood, $\mathrm{CoV}=0.45$ to 0.9$)$

$\mathrm{k}_{\mathrm{c}}=$ climate parameter $(0.5$ to 3 for diff. regions, $\mathrm{CoV}=0.55)$

For treated wood, $\quad r_{t r}=\frac{r_{u n t}}{1+B \times C_{C C A-e q}}$

Where: $\mathrm{B}=45$ for softwoods and 12 for hardwoods,

$\mathrm{C}_{\mathrm{CCA}-\mathrm{eq}}=$ equivalent preservative retention (assumed 80\%)

The initial bending strength of the pole is give as:

$$
R_{o}=\frac{\pi}{32} D^{3} f_{\text {ult }}
$$

where $R_{o}$ is the initial strength.

While the bending strength at time $t$ is given as:

$$
R_{t}=\frac{\pi}{32}\left(D-2 d_{t}\right)^{3} f_{u l t}
$$

\subsubsection{Steel Poles}

The primary cause of deterioration in steel poles is corrosion. The corrosion rate of galvanized steel is usually higher at or near the soil surface because of the availability of oxygen (Robinson, 2005). The maximum bending stress for poles is also near the ground level. 
Unlike other zinc-based coated steels where there is a pure zinc layer on top of the steel, the diffusion during the hot-dipping of galvanized steel causes the formation of a series of zinc-iron alloy layers (Romanoff, 1957). These layers result in a much slower rate of corrosion in galvanized steel than other zinc-coated steels.

Corrosion reduces the strength of steel poles by reducing the cross-sectional area and bearing capacity at the location of corrosion. There are therefore, two issues that determine the service life of steel poles. The first is the corrosion rate of the galvanized zinc coating and the second is the corrosion rate of the underlying steel.

The rate of corrosion of steel poles depends on several factors such as quality of initial corrosion prevention measures, soil type, mechanical damage, atmospheric chemical attack, fatigue, height of water table, metallurgical structure of galvanized layer, protective painting, duration of storage, and the presence of bacteria in soil. These parameters cannot be described with adequate accuracy and consequently, any corrosion rate model can only be a rough estimate.

The most extensive and comprehensive research on underground corrosion of plain and galvanized steel was conducted by the National Bureau of Standards between 1910 and 1955 and the results collated and published by Romanoff (1957). More than 36,500 specimens representing 333 varieties of materials were buried in 128 locations throughout the US. The burial depths range from 18 in. to $6 \mathrm{ft}$.

Out of the all the specimens, 14,260 were ferrous materials consisting of wrought materials (steels and plain irons) and cast irons which were used to study corrosion in the primary metals. To study the corrosion of protective metallic coatings, 1,639 steel specimens coated using the hot-dipped galvanization method were buried in different types of soils and the rate of corrosion studied. Five different base metals were used that include Bessemer steel, wrought iron, plain and copper bearing steel, and open-hearth steel. 
The results from the plain steel and iron specimens showed that the properties of the soils control the rate of corrosion as specimens supplied by different manufacturers showed similar corrosion pattern. The loss of thickness with time was found to conform to the equation below.

$$
P=k T^{n}
$$

where: $\quad \mathrm{P}=$ thickness loss (mils)

$$
\begin{aligned}
& \mathrm{T}=\text { time in years } \\
& \mathrm{k} \text { and } \mathrm{n} \text { are constants }
\end{aligned}
$$

The authors found that the minimum percentage error in $\mathrm{k}$ was obtained if it is calculated for an average exposure time of 5.3 years. Consequently, the above equation is modified as shown below. The average values of $\mathrm{k}_{5.3}, \mathrm{n}$ and their corresponding standard deviations can be found in Romanoff (1957).

$$
P=k_{5.3}\left(\frac{T}{5.3}\right)^{n}
$$

The results for the galvanized coatings showed that for specimens with $85 \mu \mathrm{m}$ coatings (2 $\mathrm{oz} / \mathrm{ft}^{2}$ ), the coating layer was destroyed during a 10-year exposure period in some of the soils and pitting occurred in the underlying steel. However, for specimens with about 130 $\mu \mathrm{m}$ coatings $\left(3 \mathrm{oz} / \mathrm{ft}^{2}\right)$, the coating is destroyed in only about half of the specimens with only the specimen in one soil out of 47 having pitting in the underlying metal.

The authors concluded that the subsequent rate of corrosion of the base metal in specimens with higher coating thicknesses after the destruction of the coating layer is slower than in control specimens with no initial galvanized coating. Darbin et al. (1988) explained that the formation of a thick corrosion crust that forms around the metal during the corrosion of the coating is what slows down the eventual corrosion rate of the underlying metal. 
Another conclusion made by the authors is that the type of base metal does not affect the rate of corrosion of the galvanized coatings.

Darbin et al. (1988) presented the result of a 10 year laboratory study and analysis of 17year old buried galvanized steel samples taken from actual structures. Excellent correlation between the laboratory tests and structure samples was found to exist.

The laboratory test was divided into two parts. The first part involved burying galvanized steel samples of different coating thicknesses $(25$ to $80 \mu \mathrm{m})$ in containers filled with soil. Five types of soils were used that include red shale, black shale, artificial sea sand, clayey sand, and silty sand. The samples were extracted at equal intervals, cleaned and weighed. Corrosion was assumed to be uniform and the weight loss was translated into average loss of thickness. The second part of the laboratory test involved electrochemical tests which were used to validate the container tests. The results from both tests showed strong correlation.

The results confirmed the relationship developed by Romanoff (1957) which relates the loss of thickness and time. Based on the results, the authors suggested that $\mathrm{n}$ should be taken as 0.33 for galvanized steel.

The loss of thickness around a sample may vary depending on the heterogeneity of a soil. The loss is however assumed to be uniform and to investigate the validity of this assumption, tensile test on the samples was performed. The results showed a good correlation between the average thickness loss and the loss of tensile strength. 


\subsubsection{Assessment and Maintenance}

Various methods of condition assessment of timber poles are used by utility companies. According to a survey by Mankowski et al. (2002), a combination of visual inspection, sounding with a hammer, and boring with a drill was used by a majority of utilities. Other methods that were reported to be used by few companies include moisture meter, Shigometer, and sonic devices.

Maintenance practices for timber poles largely involve using some form of decay control. Mankowski et al. (2002) reported that some utility companies reported using Osmoplastic or copper naphthenate-based formulations for external decay control. Treatments for internal decay include metham sodium, chloropicrin, MITC-Fume, sodium flouride rods, and fused boron rods.

Visual inspection remains the most reliable method for assessing corrosion in steel poles. This includes digging below ground to inspect underground corrosion of the steel. More advanced non-destructive methods are also available such as electrochemical field potential monitoring and the Ground Line Corrosion Meter (Ostendorp, 2003; Zamanzadeh et al., 2006). 


\section{CHAPTER 3}

\section{FRAGILITY ANALYSIS OF STEEL AND TIMBER POLES}

Fragility analysis is carried out on both timber and steel poles to estimate the probabilities of failure. Deterioration models for the pole materials discussed above are incorporated in the analysis to investigate the reduction of reliability with time.

Figure 3.1 shows a flow chart of the framework to apply reliability analysis in comparing poles of different materials. 


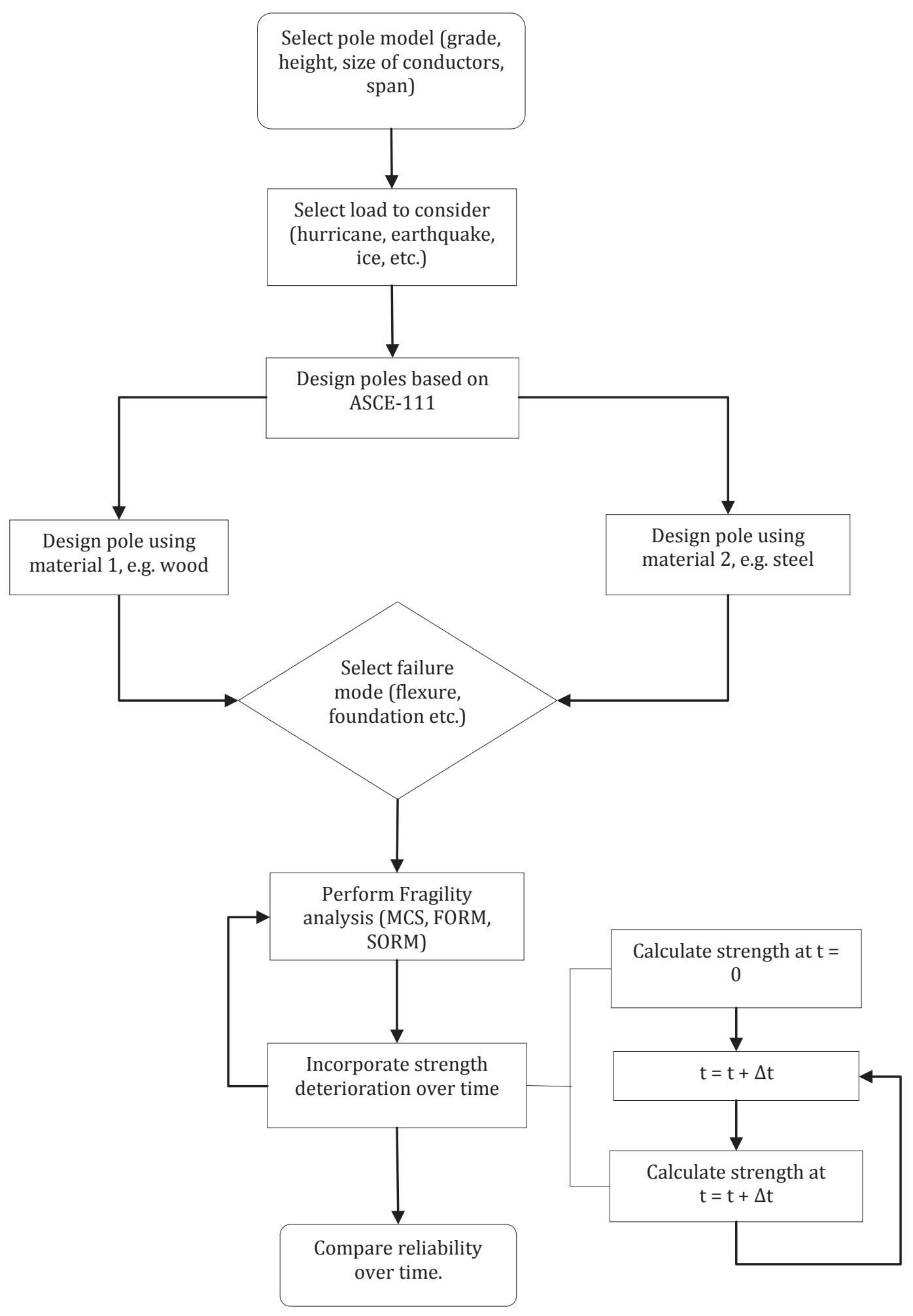

Figure 3.1: Flow chart of reliability analysis framework 


\subsection{Pole Model}

A typical distribution pole is considered for the analysis and a schematic of the pole is shown in Figure 3.2. The $6.5 \mathrm{ft}$. depth below ground is in accordance with ANSI-O5.1 (2002). Only un-guyed poles are considered in this research as they are the majority of the poles. Guyed poles tend to have lower probability of failure due to the extra support provided by the guy wires.

The conductor wires are assumed to be Aluminum Conductor Steel Reinforced (ACSR) with a diameter of $0.72 \mathrm{in}$. The poles are assumed to be located in rural areas with a span of $300 \mathrm{ft}$. for wind pressure calculations (Short, 2006).

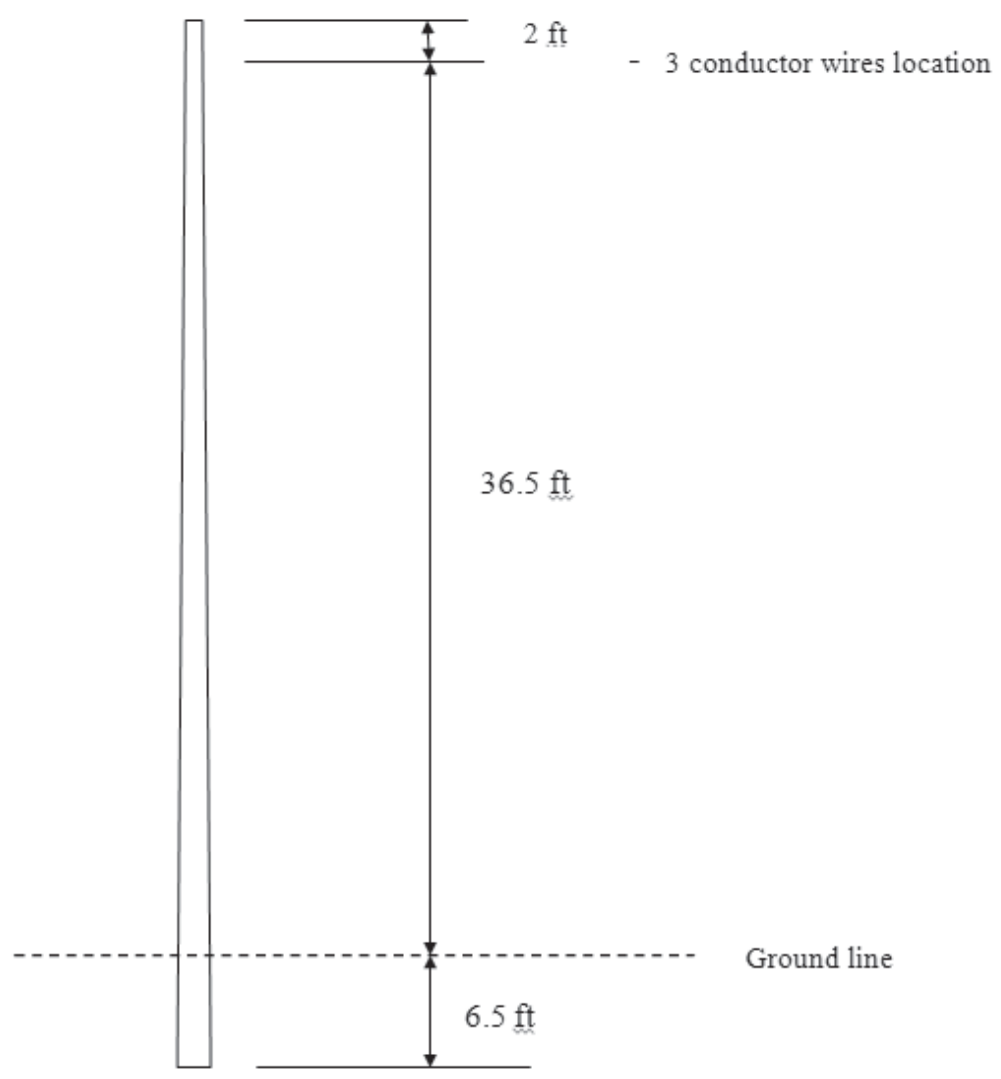

Figure 3.2: Schematic of distribution pole 


\subsection{Applied Load}

To evaluate the reliability of the distribution poles, extreme wind loads such as those experienced during hurricanes are considered. The same framework can also be extended to poles subjected to other natural hazards such as earthquakes, ice storms and so on. These weather-related loads are independent of material type, rather they depend on the geometry of the pole and the wires supported by the pole.

The design requirements in the US for transmission and distribution structures are typically based on a 50-year return period, 3-sec gust wind speed under standard atmosphere (ASCE-111, 2006). Based on the wind speed, the wind force in pounds, acting on the pole and the wires can be calculated using the equation below from ASCE Manual 74 - Guidelines for Electrical Transmission Line Structural Loading. ASCE-111 recommends the use of this equation for both transmission and distribution support structures.

$$
\mathrm{F}=\mathrm{Q} \mathrm{K}_{\mathrm{z}} \mathrm{K}_{\mathrm{zt}}(\mathrm{V})^{2} \mathrm{G} \mathrm{C}_{\mathrm{f}} \mathrm{A}
$$

$\mathrm{Q}=$ numerical constant (air density factor) $=0.00256$

$\mathrm{K}_{\mathrm{Z}}=$ exposure coefficient $=2.01 \times\left(\mathrm{Z}_{\mathrm{h}} / \mathrm{Z}_{\mathrm{g}}\right)^{2 / \alpha}$, where $\mathrm{Z}_{\mathrm{h}}$ is effective height, $\mathrm{Z}_{\mathrm{g}}$ is gradient height (height above which wind speed is assumed to be constant) and $\alpha$ is the power law exponent which accounts for wind profile with respect to height $\left(Z_{g}=900\right.$ and $\alpha=9.5$ for exposure category $\mathrm{C}$ ).

$\mathrm{V}=$ Basic 3-sec gust wind speed measured at $33 \mathrm{ft}$ above ground in flat and open country terrain (Exposure category $\mathrm{C}$ ).

$\mathrm{G}=$ gust response factor which accounts for dynamic effects and lack of correlation of gusts on the wind response. 


$$
\begin{aligned}
& \text { For poles: } G_{t}=\frac{1+2.7 E \sqrt{B_{t}}}{K_{v}^{2}} \quad \text { For wires: } G_{w}=\frac{1+2.7 E \sqrt{B_{w}}}{K_{v}^{2}} \\
& E=4.9 \sqrt{k}\left(\frac{33}{Z_{h}}\right)^{\frac{1}{\alpha F_{M}}} \quad B_{w}=\frac{1}{1+\frac{0.8 S}{L_{s}}} \quad B_{t}=\frac{1}{1+\frac{0.56 Z_{h}}{L_{s}}}
\end{aligned}
$$

Where $\mathrm{S}$ is design wind span (ft.), $\mathrm{K}_{\mathrm{v}}=1.43$, and $\alpha_{\mathrm{FM}}, \mathrm{k}$, and $\mathrm{L}_{\mathrm{s}}$ are wind parameters.

$\mathrm{C}_{\mathrm{f}}=$ force or drag coefficient (shape factor)

$\mathrm{K}_{\mathrm{zt}}=$ topographic factor

$\mathrm{A}=$ the area projected on a plane normal to the wind direction $\left(\mathrm{ft}^{2}\right)$.

The worst case scenario is when the wind load acts perpendicular to the conductors as this produces the largest bending stress at the ground line of the pole. This is assumed in developing the fragility models in this research.

The wind force acting on a pole varies as most of the variables above are uncertain variables. To properly capture the variation of the force, the distributions and coefficient of variations $(\mathrm{CoV})$ of the above random variables are considered in this research and are summarized in Table 3.1 .

Table 3.1: Wind load parameters and statistics

\begin{tabular}{|l|l|l|l|l|l|}
\hline $\begin{array}{l}\text { Random } \\
\text { variable }\end{array}$ & $\begin{array}{l}\text { Mean values } \\
\text { for pole }\end{array}$ & $\begin{array}{l}\text { Mean values for } \\
\text { wires }\end{array}$ & $\begin{array}{l}\text { Probability } \\
\text { distribution }\end{array}$ & CoV & Source \\
\hline $\mathrm{G}$ & 0.948 & 0.801 & Normal & 0.11 & $\begin{array}{l}\text { Ellingwood and Tekie } \\
(1999)\end{array}$ \\
\hline $\mathrm{C}_{\mathrm{f}}$ & 0.9 & 1.0 & Normal & 0.12 & $\begin{array}{l}\text { Ellingwood and Tekie } \\
(1999)\end{array}$ \\
\hline $\mathrm{K}_{\mathrm{z}}$ & 0.951 & 1.024 & Normal & 0.06 & ASCE - 111 (2006) \\
\hline $\mathrm{Q}$ & 0.00256 & 0.00256 & - & - & - \\
\hline $\mathrm{K}_{\mathrm{zt}}$ & 1.0 & 1.0 & - & - & - \\
\hline
\end{tabular}




\subsection{Design of Timber Pole}

Since the wind load is going to be varied to generate the fragility curve of the poles, an arbitrary timber pole can be selected without going through the usual design process. Since Southern Pine is the most commonly used species (Wolfe \& Moody, 1997) and the most common class is Class 4 (Foedinger et al., 2003), they are chosen for the purpose of this research. The properties of the chosen pole are given below (ANSI-O5.1, 2002):

Species: $\quad$ Southern Pine

Class: $\quad 4$

Tip diameter: $\quad 6.69$ in.

Ground line diameter: $\quad 11.14$ in.

Distance to centroid: $\quad 17.65 \mathrm{ft}$.

Mean moment capacity at ground line $=$ stress $\mathrm{x}$ section modulus $=90,482 \mathrm{ft}-\mathrm{lb}$

The uncertainties in the calculation of the moment capacity of the timber pole are summarized in Table 3.2.

Table 3.2: Timber pole parameters and statistics

\begin{tabular}{|l|l|l|l|l|l|}
\hline $\begin{array}{l}\text { Random } \\
\text { variable }\end{array}$ & $\begin{array}{l}\text { Mean } \\
\text { values for } \\
\text { pole }\end{array}$ & $\begin{array}{l}\text { Mean } \\
\text { values for } \\
\text { wires }\end{array}$ & $\begin{array}{l}\text { Probability } \\
\text { distribution }\end{array}$ & CoV & Source \\
\hline $\begin{array}{l}\text { Fiber Stress } \\
\text { psi) }\end{array}$ & 8,000 & - & Lognormal & $\begin{array}{l}\text { Varies with } \\
\text { time }\end{array}$ & ANSI-O5.1 (2002) \\
\hline $\begin{array}{l}\text { Height above } \\
\text { ground (ft.) }\end{array}$ & 38.5 & 36.5 & Normal & 0.03 & Assumed \\
\hline $\begin{array}{l}\text { Wind Area } \\
\left.\mathrm{ft}^{2}\right)\end{array}$ & 28.6 & 54 & Normal & 0.06 & $\begin{array}{l}\text { Wolfe and Moody } \\
(1997)\end{array}$ \\
\hline
\end{tabular}


The pole is assumed to be located in Iowa and the deterioration model developed by Yuan Li et al. (2005) discussed earlier was used to investigate the reduction in reliability over time. The penetration time is taken as 10 years as suggested in the model.

\subsection{Design of Steel Pole}

To allow comparison, an 'equivalent' steel pole will be designed so as to obtain similar initial reliability for both the timber pole selected above and the steel pole. The allowable (failure) stress of circular steel poles can be calculated using the equations below from ASCE Manual 72 - Design of Transmission Pole Structures (1990).

$$
\begin{aligned}
& \text { If } \frac{D}{t} \leq \frac{6000}{F_{y}} \text { then yielding controls and } F_{b}=F_{y} \\
& \text { If } \frac{6000}{F_{y}}<\frac{D}{t} \leq \frac{12000}{F_{y}} \text { then local buckling controls and } F_{b}=0.70 F_{y}+\frac{1800}{D / t}
\end{aligned}
$$

Where: $F_{\mathrm{y}}=$ yield stress $(65 \mathrm{ksi})$

$$
\begin{aligned}
& \mathrm{D}=\text { outer diameter } \\
& \mathrm{t}=\text { thickness } \\
& \mathrm{F}_{\mathrm{b}}=\text { allowable (failure) bending stress (ksi) }
\end{aligned}
$$

According to Bolin and Smith (2011), steel poles are usually tapered and have similar dimensions as timber poles of the same class and length. Therefore, assuming a steel pole with the same tip and ground line diameter and moment capacity as the timber pole above (6.69 in., 11.14 in. and 90,482 ft-lb respectively), the required thickness is back calculated, assuming yielding controls, as 0.18 in. as shown below: 


$$
\begin{aligned}
& d_{o}=11.14 \mathrm{in.} \quad t=0.18 \mathrm{in.} \quad d_{i}=d_{o}-2 t=10.78 \mathrm{in} . \\
& S=\frac{\pi\left(d_{o}^{4}-d_{i}^{4}\right)}{32 d_{o}}=16.71 \mathrm{in}^{3} \\
& F_{b}=65000 \mathrm{lb} / \mathrm{in}^{2} \\
& M=F_{b} S=90522.82 \mathrm{ft}-\mathrm{lb} \\
& \frac{d_{o}}{t}=61.89 \quad \frac{6000}{65}=92.31 \\
& \text { Since } \frac{d_{o}}{t}<\frac{6000}{F_{y}} \quad \text { Therefore, assumption that yielding controls is correct. }
\end{aligned}
$$

The thickness of $0.18 \mathrm{in}$. is typical for a steel pole from manufacturers that is designated as an equivalent of Class 4 timber pole. The uncertainties in the calculation of the capacity of the steel pole are summarized in Table 3.3 below.

Table 3.3: Steel pole parameters and statistics

\begin{tabular}{|l|l|l|l|l|}
\hline Random variable & Values & $\begin{array}{l}\text { Probability } \\
\text { distribution }\end{array}$ & CoV & Source \\
\hline Yield Stress (psi) & 65,000 & Normal & 0.1 & ASCE - 74 (1991) \\
\hline $\begin{array}{l}\text { Height above } \\
\text { ground (ft.) }\end{array}$ & 38.5 & Normal & 0.03 & Assumed \\
\hline Wind Area $\left(\mathrm{ft}^{2}\right)$ & 28.6 & Normal & 0.06 & Assumed same as timber \\
\hline
\end{tabular}

Based on the thickness of the steel pole and requirement of ASTM A123, the minimum coating thickness required is $75 \mu \mathrm{m}$ as can be seen in Table 2.4 of the previous chapter. 
To get the corrosion rate, the relationship developed by Romanoff (1957), described previously, was used. The pole is assumed to be located in Iowa so as to allow comparison with the timber poles. The Muscatine silt loam soil in Iowa has a $\mathrm{K}_{5.3}$ value of 32.1 mils and a standard deviation of 7 mils. Based on the recommendation by Darbin et al. (1988), $\mathrm{n}$ is taken as 0.33 .

AS/NZS-2041 (1998) suggested a corrosion rate for the galvanized zinc layer based on $\mathrm{pH}$ and resistivity of the soil. The corrosion rate based on $\mathrm{pH}$ is shown in Table 3.4. The $\mathrm{pH}$ of the Muscatine silt loam soil in the chosen location in Iowa ranges from $6-7$ and has fair drainage ability (Miller et al., 2010; Romanoff, 1957). Based on these, the corrosion rate of the zinc layer will be $2.2-4.3 \mu \mathrm{m}$ per year. For a $75 \mu \mathrm{m}$ coating, this translates to a life expectancy of $17-34$ years.

Table 3.4: Corrosion rates of zinc coating (AS/NZS-2041, 1998)

\begin{tabular}{|c|c|c|}
\hline \multirow{2}{*}{ SOIL $\mathrm{pH}$} & \multicolumn{2}{|c|}{$\mathrm{pH}$ versus zinc corrosion rate } \\
\cline { 2 - 3 } & AVERAGE ZINC COATING LOSS - /YEAR \\
\hline$<4$ & Drained soils & Undrained soils \\
\hline $4-4.9$ & $<4$ & $>6.5$ \\
\hline $5-7.9$ & $4-4.9$ & $2.6-5.2$ \\
\hline $8-9$ & $5-7.9$ & $2.2-4.3$ \\
\hline$>9$ & $8-9$ & $3.3-6.5$ \\
\hline
\end{tabular}

The American Galvanizers Association published charts for predicting the service life of zinc coating depending on moisture content and $\mathrm{pH}$ of soils. The charts were developed from studies carried out for the National Corrugated Steel Pipe Association (NCSPA). Based on the charts, for a silt loam soil with fair drainage and a $\mathrm{pH}$ of $6-7$, the service life of the $75 \mu \mathrm{m}$ zinc coating is about 25 years (AGA, 2011). 
The service life of the zinc coating is assumed to be 20 years in this study which is conservative based on the above recommendations. Therefore, the steel will only start corroding after 20 years which means that to get the loss in strength when the pole is 40 years old, $\mathrm{T}=20$ years will be used in the equation.

To calculate the increase in stress due to reduction in thickness, the inner diameter is kept constant while the outer diameter is calculated as the inner diameter plus twice the thickness at any time t.

\subsection{Risk Assessment}

\subsubsection{Fragility Analysis}

Using the above information, Monte Carlo simulation, described previously, was performed to calculate the probability of failure of the poles while varying the basic 3-sec gust wind speed. For each random variable, 1,000,000 random values were generated. Fragility curves were then generated. For each wind speed, the number of cases where the stress demand at the ground line exceeds the corresponding stress capacity was counted.

Only flexural failure due to wind loads at the ground line is considered in this research. According to ASCE-111 (2006), for short poles ( $<60 \mathrm{ft}$. tall) such as the ones in distribution systems, the critical stress point is usually at the ground line. However, the same framework can be applied to other failure modes such as foundation failure or failure due to unbalanced load caused by the failure of adjacent poles.

The limit state function of the flexural failure mode is given as:

$$
\mathrm{g}(\mathrm{x})=\mathrm{C}-\mathrm{L}=\sigma_{\mathrm{c}}-\sigma_{\mathrm{L}}
$$

Where $\mathrm{C}$ is capacity, $\mathrm{L}$ is load, $\sigma_{\mathrm{c}}$ is stress capacity, $\sigma_{\mathrm{L}}$ is stress due to load at ground line. 
For the timber pole: $\sigma_{\mathrm{c}}=8000 \mathrm{psi}$

$$
\sigma_{L}=\frac{M_{g}}{S} \quad S=\frac{\pi D^{3}}{32}
$$

Where: $\mathrm{M}_{\mathrm{g}}$ is moment at ground line due to wind on pole and wires.

For steel pole: $\sigma_{\mathrm{c}}=65 \mathrm{ksi}$ (yielding controls as shown previously)

$$
S=\frac{\pi\left(d_{o}^{4}-d_{i}^{4}\right)}{32 d_{o}}
$$

To allow comparison between the timber and steel poles, the reduction in strength of the timber pole is calculated considering the conditional probability of decay and otherwise using the equation developed by Yuan Li et al. (2005). If the conditional probability of decay is to be considered, the strength of the timber pole at any age is given by:

$$
R(t)=R_{o}\left[1-\left(a_{1} t-a_{2}\right)\left(b_{1} t-b_{2}\right)\right]
$$

Since there is no data to calculate the probability of corrosion of the steel pole, accurate comparison with the timber pole can only be made when the probability of decay of the timber poles is ignored. Consequently, the timber pole is assumed to start decaying immediately after the penetration period has lapsed. The steel pole is assumed to start corroding after the zinc coating is completely corroded.

If the conditional probability of decay is not to be considered, the strength of the pole at any time is given as:

$$
R(t)=R_{o}\left[1-\left(a_{1} t-a_{2}\right)\right]
$$

It should be noted that maintenance of the timber and steel poles is not considered in this analysis. Utility companies have inspection and maintenance schedules to make sure that the strength of the poles does not fall below a certain value. Visual inspection and other methods such as the use of Ground Line Corrosion Meter are employed. These methods 
however have a lot of uncertainties. Some utilities also apply protective paints to bottom portion of galvanized steel poles so as to improve corrosion resistance. This is also not considered in the analysis. If specific information about maintenance and additional corrosion protection is available, the framework can readily be extended to accommodate this information.

\subsubsection{Annual Probability of Failure}

To estimate the annual probabilities of failure of the poles, the fragility analysis is convolved with the hurricane wind speed model as proposed by Yue Li and Ellingwood (2006). The annual probability of failure is given by:

$$
P_{f}=\int_{0}^{\infty} F_{R}(v) f_{V}(v) d v
$$

Where $F_{R}(v)$ is the structural fragility as described in the section above and $f_{v}(v)$ is the probability density function (PDF) of the hurricane wind speed. The equation is solved using numerical integration. Vickery et al. (2000) conducted simulations of hurricanes and proposed that the Weibull distribution is appropriate for hurricane wind speed prediction. The PDF of the Weibull equation is given as:

$$
f_{v}(v)=\frac{\alpha}{u}\left(\frac{v}{u}\right)^{\alpha-1} \exp \left[-\left(\frac{v}{u}\right)^{\alpha}\right]
$$

The wind speed is related to the return period $(\mathrm{T})$ of the hurricane by the equation below.

$$
v=u\left[-\ln \left(\frac{1}{T}\right)\right]^{\frac{1}{\alpha}}
$$

Assuming that the location of the poles is inland (Iowa), the 100 and 500 year return period peak gust wind speeds are obtained as 90 and 110 mph from Vickery et al. (2000). 
Using these wind speeds, the parameters of the Weibull distribution are obtained as $\mathrm{u}=$ 32.378 and $\alpha=1.494$.

Based on the above equation and parameters, the wind hazard curve for Iowa is plotted as shown in Figure 3.3.

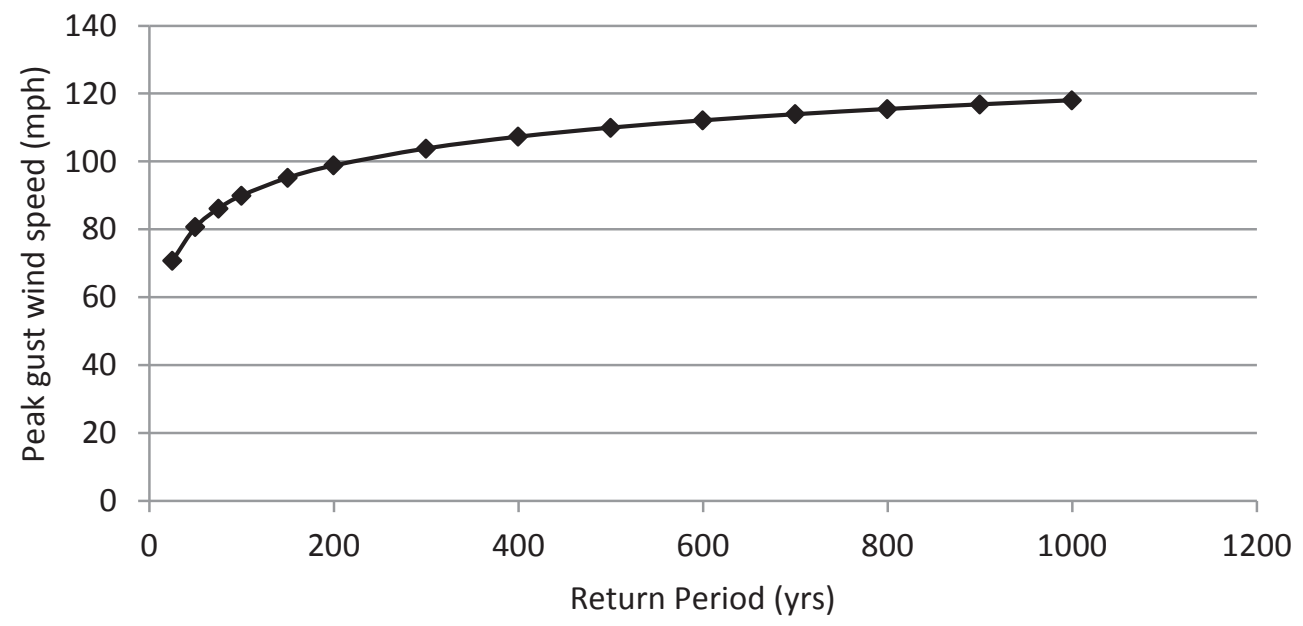

Figure 3.3: Wind hazard curve for Iowa

If the poles are assumed to be located in a coastal area at the southern end of Florida, the Weibull distribution parameters are calculated as $\mathrm{u}=61.07$ and $\alpha=1.769$ and the wind hazard curve is shown in Figure 3.4. 


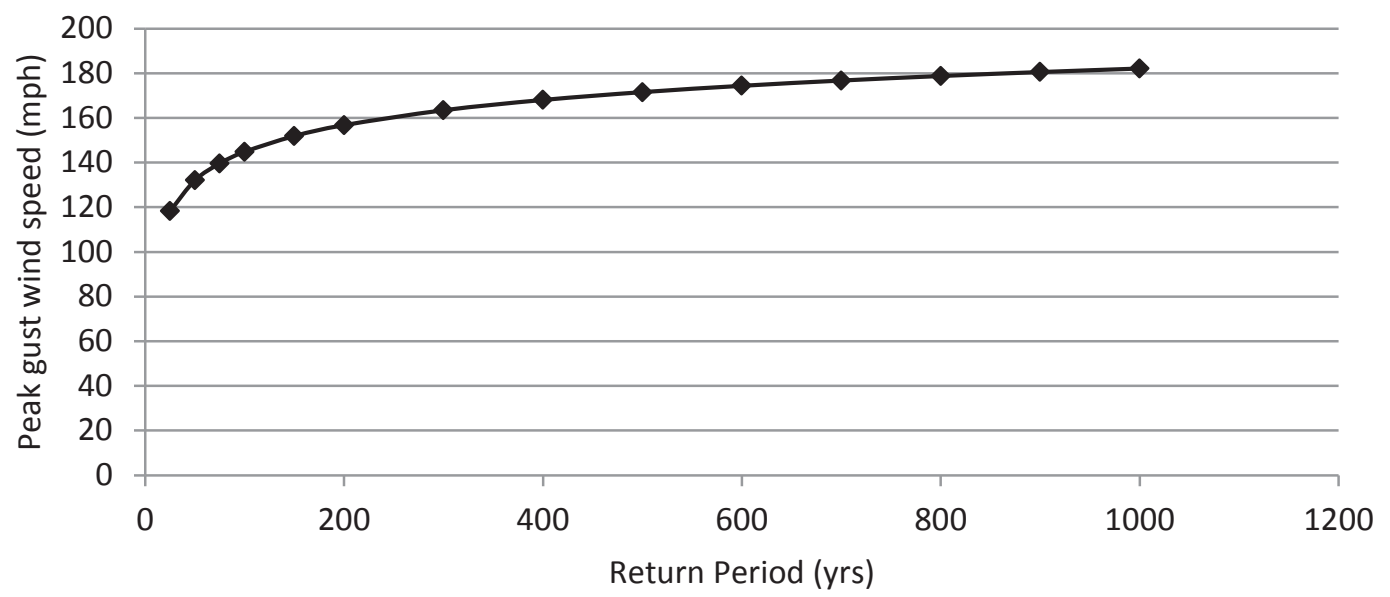

Figure 3.4: Wind hazard curve for Florida

The lognormal distribution is assumed to describe the fragility models and KolmogorovSmirnov test was carried out to confirm its validity. The lognormal distribution was also proved to be suitable by Bjarnadottir et al. (2013a). The lognormal CDF is given by,

$$
F_{R}(v)=\Phi\left[\frac{\ln \left(\frac{v}{m_{R}}\right)}{\zeta_{R}}\right]
$$

Where $F_{R}(v)$ is the structural fragility, $m_{R}$ is the median strength, $v$ is the wind speed and $\zeta_{\mathrm{R}}$ is the logarithmic standard deviation of capacity.

\subsection{Results}

The lost in strength with age for the poles is first plotted as shown in Figure 3.5. It can be seen that for the timber pole, there is a stark difference whether or not the conditional probability of decay (CPD) is considered. At 60 years, the strength of the timber pole will reduce to $85 \%$ of the original strength when CPD is considered compared to about $24 \%$ 
when it is not considered. In comparison, the strength of the steel pole dropped to about $69 \%$ of the original strength at 60 years. It can also be seen that the rate of deterioration of the steel pole decrease with time unlike the timber pole. This is due to the power model used for the corrosion of steel where the value of $\mathrm{n}$ in the equation is less than 1 .

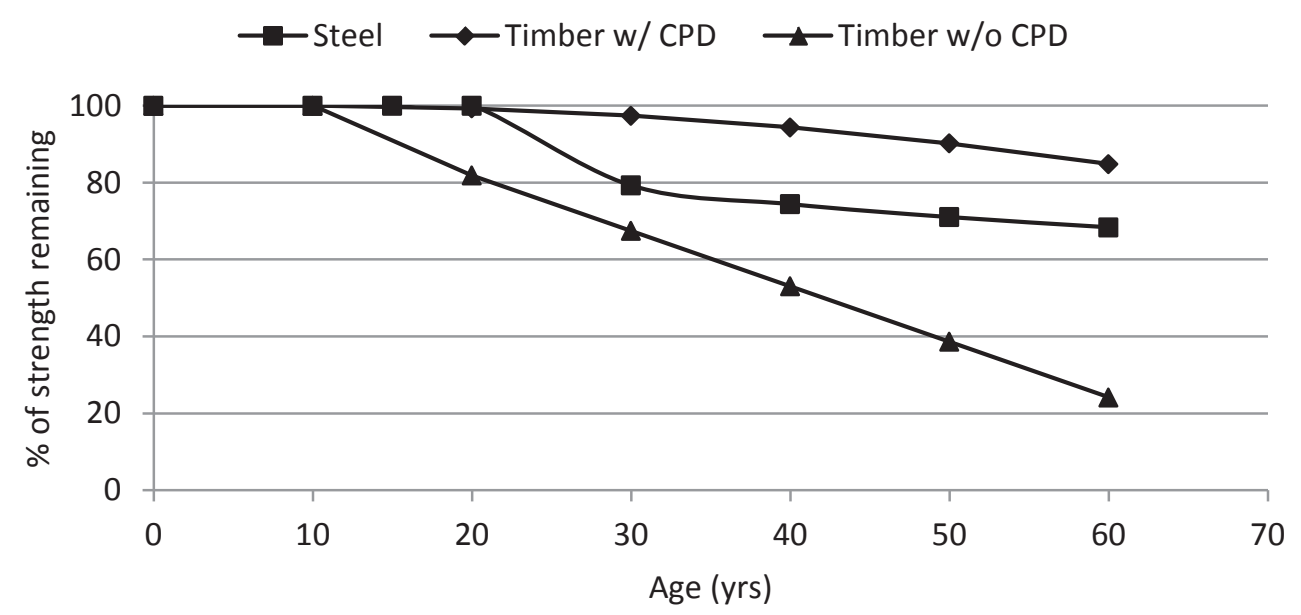

Figure 3.5: Percentage of strength remaining over time

The fragility curves of the steel and timber poles at time of installation $(t=0)$ are shown in Figure 3.6. It can be seen that as expected, the fragilities are very similar which will allow comparison between the poles as they start to deteriorate. 


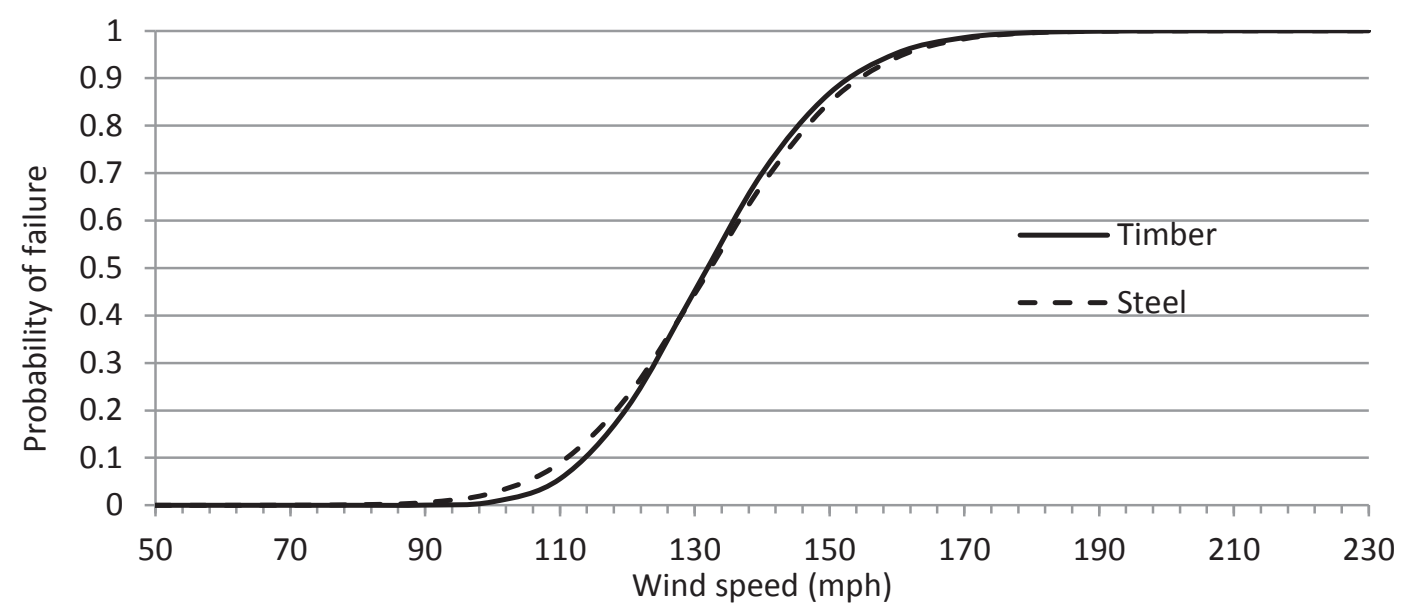

Figure 3.6: Fragility curve of new timber and steel poles

The fragility curves of the poles at 20, 40 and 60 years are shown in Figures 3.7 to 3.9. It can be seen that as the poles age, their reliability decreases as implied by the increase in probabilities of failure. For example at $130 \mathrm{mph}$, the probabilities of failure of the timber pole considering CPD are $0.47,0.56$, and 0.68 at 20, 40, and 60 years respectively. The corresponding probabilities are 0.77, 0.98, and 1.00 if CPD is not considered. As expected, these are much lower than when CPD is considered. For the steel pole, the probabilities of failure at 20,40, and 60 years are $0.44,0.86$, and 0.92 respectively.

It can also be seen that when CPD is considered, the timber pole has higher reliability than the steel pole at 40 and 60 years. However, when CPD is not considered, then the steel pole has higher reliability than the timber pole at all ages. For example at 40 years and a wind speed of $100 \mathrm{mph}$, the probabilities of failure are $0.05,0.19$ and 0.63 for timber with CPD, steel, and timber without CPD. This implies that if the steel and timber poles are assumed to start deteriorating immediately after the initial protection (chemical treatment and galvanizing) has run its course, which is about 10 years for timber and 20 years for steel, then the steel poles have better reliability with age. 
The figures also show that as the pole ages, the rate of deterioration of the steel pole is slower than that of the timber pole especially if CPD is not considered. This reflects the pattern seen in the plot of pole strengths with age in Figure 14 above.

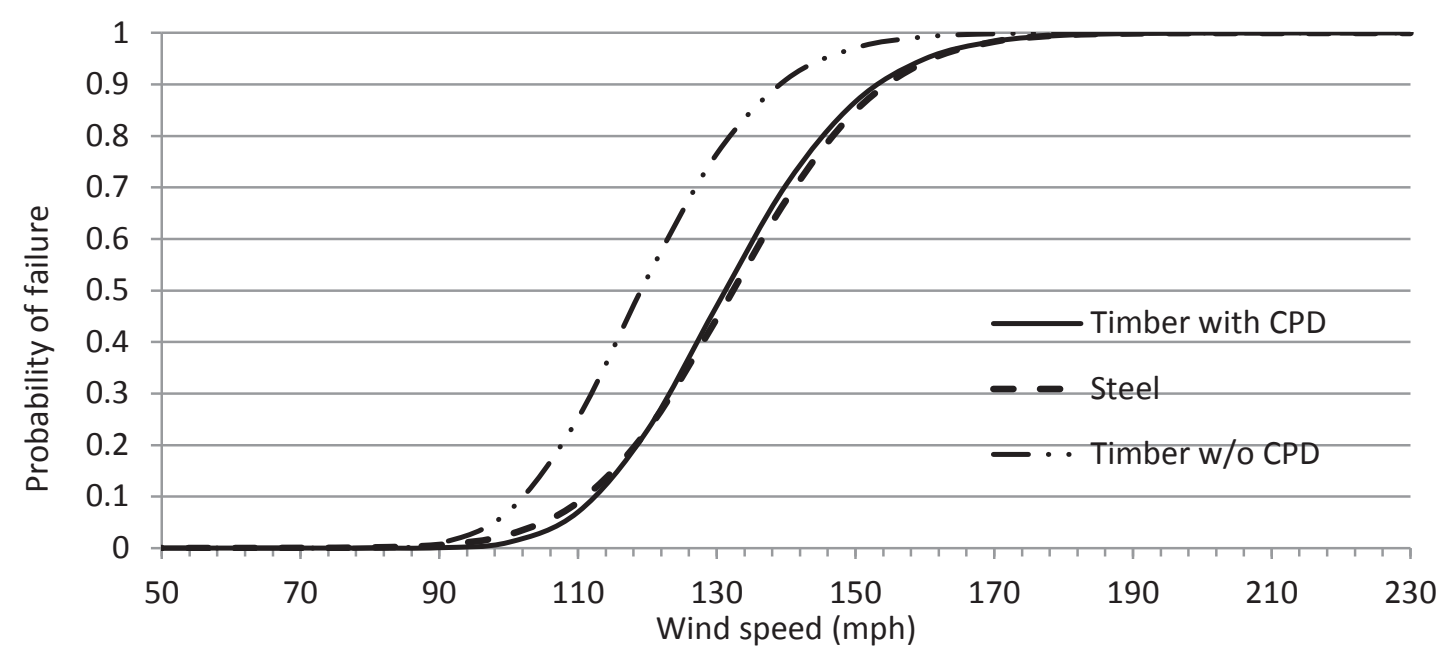

Figure 3.7: Fragility curves of timber and steel poles at 20 years

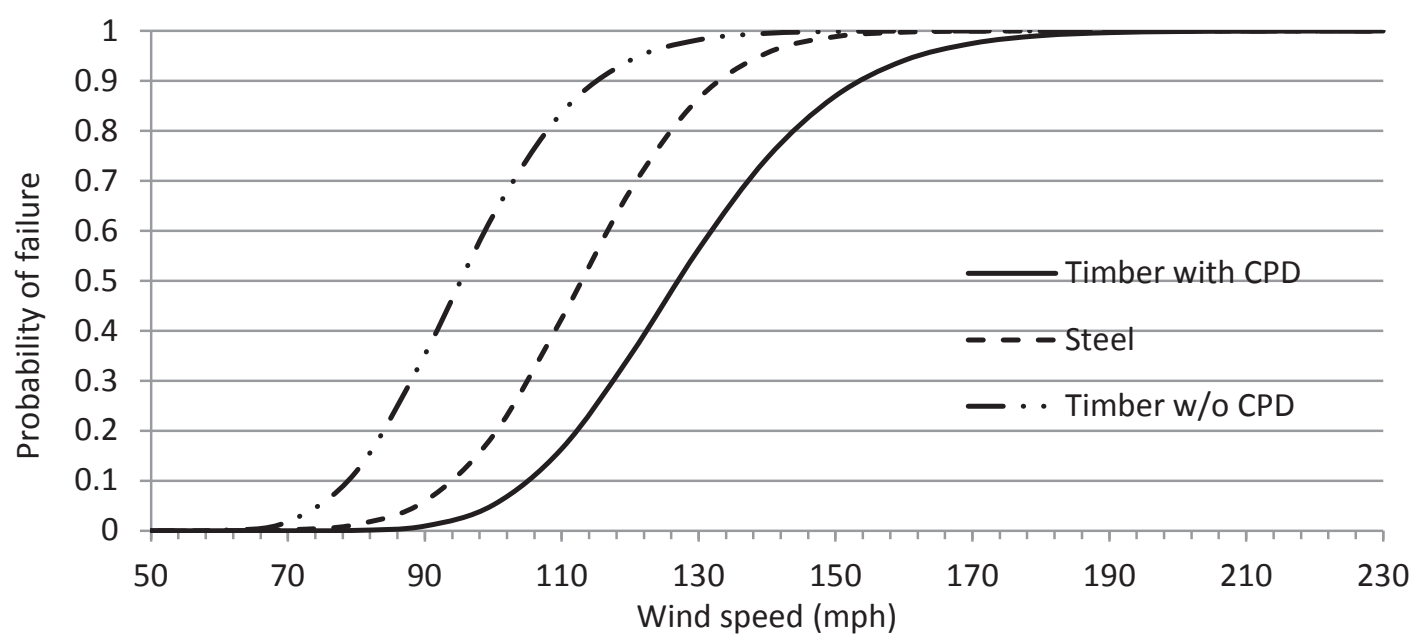

Figure 3.8: Fragility curves of timber and steel poles at 40 years 


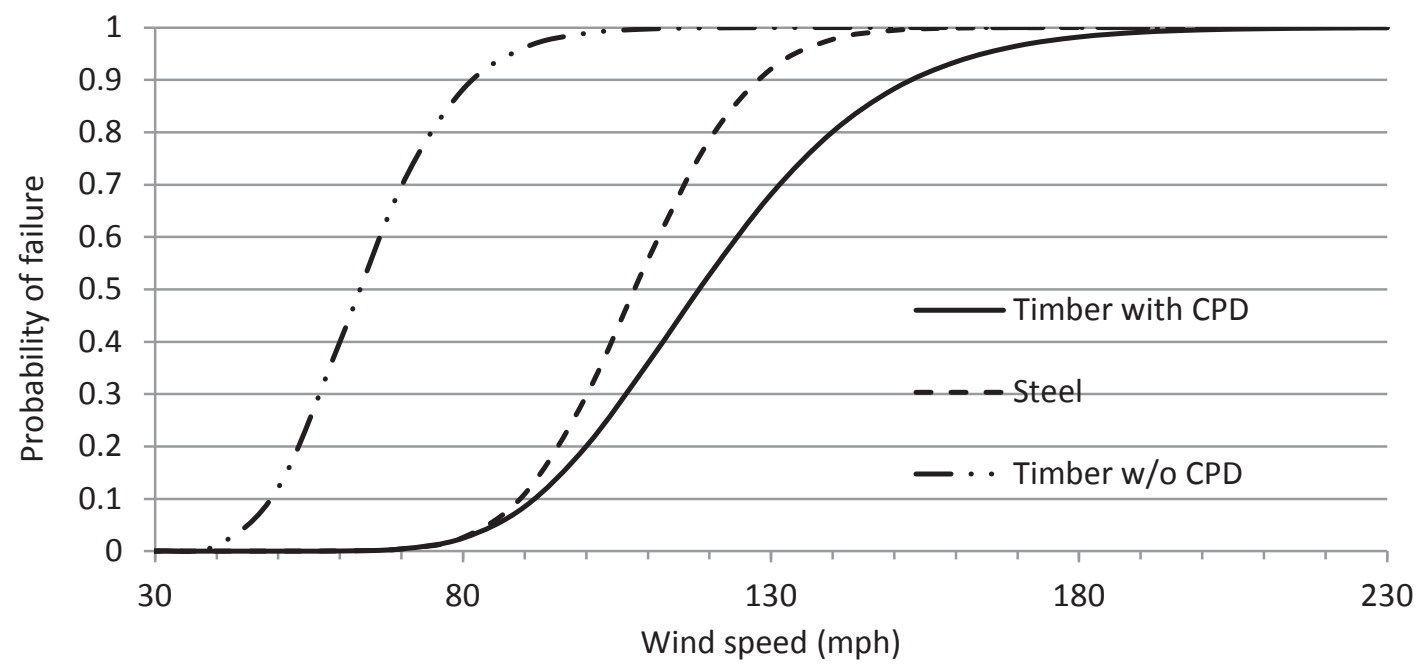

Figure 3.9: Fragility curves of timber and steel poles at 60 years

The annual probabilities of failure of the poles calculated by convolving the fragilities above and the wind speed distribution at different ages are given in Table 3.5 and plotted in Figure 3.10.

Table 3.5: Annual probabilities of failure for poles located in Iowa

\begin{tabular}{|l|c|c|c|c|}
\hline \multirow{2}{*}{ Pole Type } & \multicolumn{4}{|c|}{ Age (years) } \\
\cline { 2 - 5 } & 0 & 20 & 40 & 60 \\
\hline $\begin{array}{l}\text { Timber with } \\
\text { CPD }\end{array}$ & 0.0006 & 0.0007 & 0.0012 & 0.0036 \\
\hline $\begin{array}{l}\text { Timber w/o } \\
\text { CPD }\end{array}$ & 0.0006 & 0.0017 & 0.0106 & 0.0824 \\
\hline \begin{tabular}{l} 
Steel \\
\hline
\end{tabular} & 0.0007 & 0.0007 & 0.0027 & 0.0040 \\
\hline
\end{tabular}




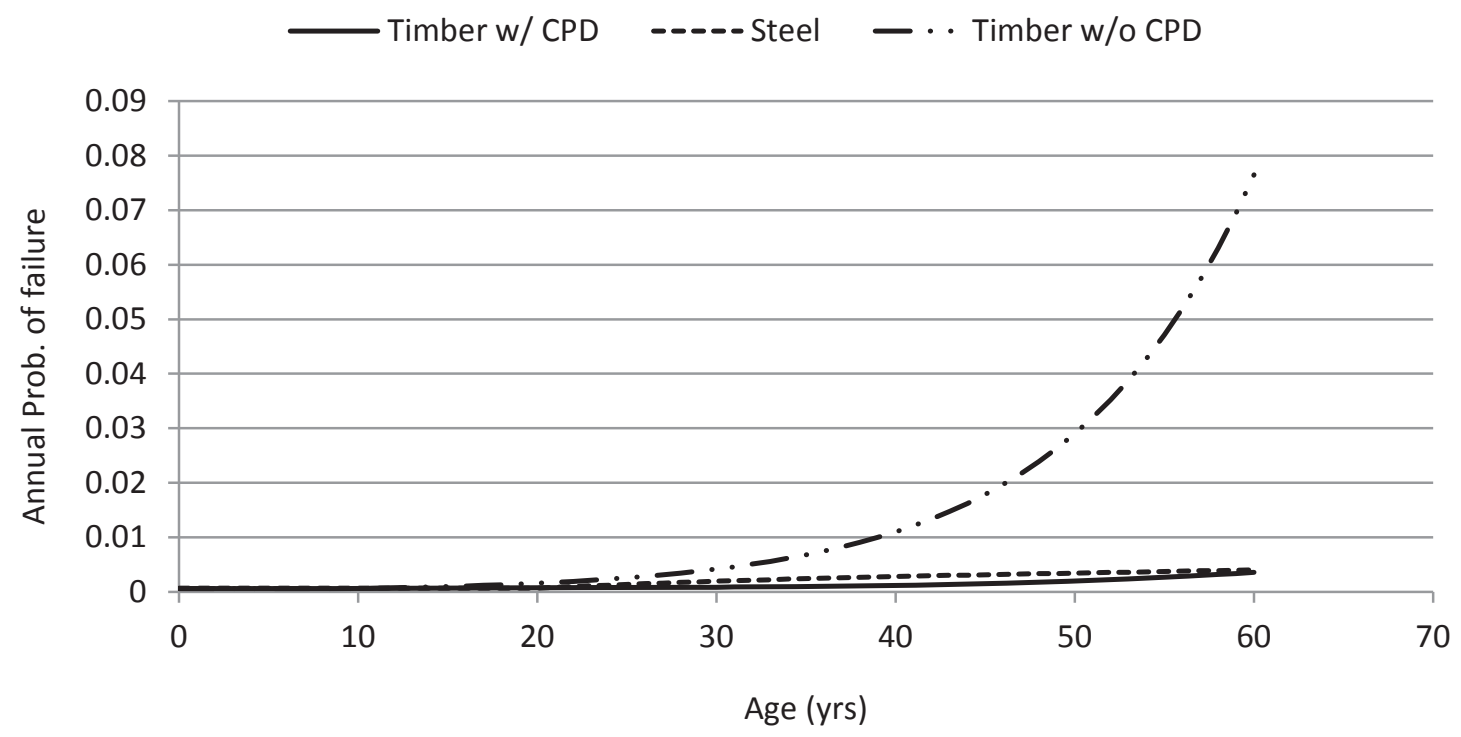

Figure 3.10: Annual probabilities of failure for poles located in Iowa

The above annual probabilities of failure are very small due to the fact that the assumed location of the poles is far inland (Iowa) which means that the probability of having high wind speed hurricanes, calculated using the Weibull parameters discussed in Section 3.5.2, is very small. If the poles are assumed to be located in a coastal area at the southern end of Florida, the Weibull distribution parameters are calculated as $u=61.07$ and $\alpha=$ 1.769, and the annual probabilities of failure are given in Table 3.6 and plotted in Figure 3.11 .

Table 3.6: Annual probabilities of failure for poles located at the southern end of Florida

\begin{tabular}{|l|c|c|c|c|}
\hline \multirow{2}{*}{ Pole Type } & \multicolumn{4}{|c|}{ Age (years) } \\
\cline { 2 - 5 } & 0 & 20 & 40 & 60 \\
\hline Timber w/ CPD & 0.0252 & 0.0271 & 0.0350 & 0.0585 \\
\hline Timber w/o CPD & 0.0252 & 0.0460 & 0.1245 & 0.3544 \\
\hline Steel & 0.0260 & 0.0260 & 0.0598 & 0.0740 \\
\hline
\end{tabular}




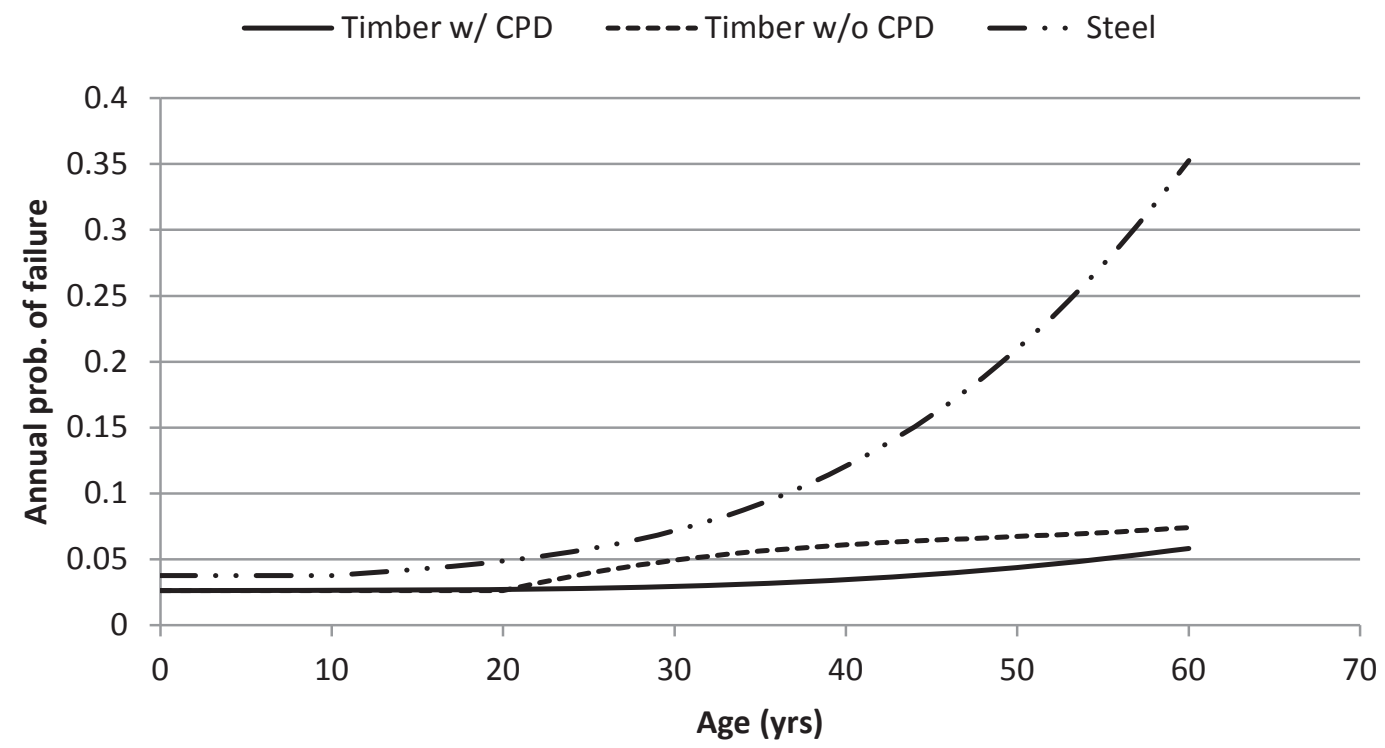

Figure 3.11: Annual probabilities of failure for poles located at the southern end of Florida

From Tables 3.5 and 3.6 above, it can be seen that the steel pole have higher annual probabilities of failure over the years than the timber pole when CPD is considered. However, when CPD is not considered, the steel pole shows much lower failure probabilities over the years.

Bjarnadottir et al. (2013a) calculated the annual probability of failure of a 1 year old class 3 timber pole in Florida as 0.02. This is similar to the result shown in Table 3.6 above where the new Class 4 timber pole shows an annual probability of failure of 0.025 . 


\section{CHAPTER 4}

\section{LIFE-CYCLE COST ANALYSIS OF STEEL AND TIMBER POLES}

A life-cycle cost analysis is performed to compare the timber and steel poles considering both deterioration of strength with time and fragility of the poles. For a distribution line with $\mathrm{n}$ number of poles, the present value of the life-cycle cost can be calculated using the equation below adopted and modified from Bjarnadottir et al. (2013b) and Wen and Kang (2001).

$$
L C C=n C_{o}+\left[\sum_{t=1}^{\tau} n P(\mathrm{X}, \mathrm{t})\right] \frac{C_{r e p}}{(1+r)^{t}}+\int_{0}^{t} \frac{C_{m}(X)}{(1+r)^{t}} d \tau
$$

Where: $\quad \mathrm{n}=$ number of poles in the line;

$$
\begin{aligned}
& \mathrm{C}_{\mathrm{o}}=\text { initial cost per pole; } \\
& \tau=\text { total number of years being considered; } \\
& \mathrm{P}=\text { probability of limit state being exceeded; } \\
& \mathrm{X}=\text { design variable vector (design loads and resistance); } \\
& \mathrm{t}=\text { time; } \\
& \mathrm{C}_{\mathrm{rep}}=\text { cost of replacement; } \\
& (1+\mathrm{r})^{\mathrm{t}}=\text { discounted factor over time } \mathrm{t} ; \\
& \mathrm{r}=\text { constant discount rate/year; } \\
& \mathrm{C}_{\mathrm{m}}=\text { operation and maintenance cost per year. }
\end{aligned}
$$

In developing the above equation, the following assumptions were made:

i. All poles are installed at the same time, i.e., at $t=0$ all poles are assumed to be new. 
ii. All poles in the line are subjected to the same load level.

iii. The probability of failure is the same for all poles of the same age. Consequently, the number of poles that fail every year is obtained by multiplying the probability of failure of one pole with the total number of poles in that age group.

iv. Failure of poles is assumed to be independent.

v. Poles are assumed to deteriorate following the deterioration models discussed previously.

To carry out the life-cycle analysis, a distribution line with a total of 100,000 poles is considered. The cost is calculated when all the poles are timber poles and again when the poles are steel poles. The time frame considered for analysis is 60 years as suggested by Bolin and Smith (2011).

The age distribution of the poles changes every year because poles that failed due to hurricane winds are being replaced continuously. A matrix is therefore generated with the number of poles in each age group at any given year within the period being considered. This is essential to ensure that the number of poles in each age group is multiplied by the appropriate probability of failure which varies with age.

\subsection{Initial Cost}

The initial cost of construction includes cost of purchasing, shipping and handling, and cost of installation. The initial costs of timber and steel poles in US dollars used in this study are given in Table 4.1 (Bjarnadottir et al., 2013b; Butera, 2000; X. H. Li, 2004). 
Table 4.1: Initial cost of timber and steel poles

\begin{tabular}{|l|c|c|}
\hline \multirow{2}{*}{ Costs } & \multicolumn{2}{|c|}{ Pole Type } \\
\cline { 2 - 3 } & Timber Pole (Class 4 SP) & Steel Pole \\
\hline Purchase, shipping \& handling (\$) & 320 & 600 \\
\hline Installation (\$) & 520 & 260 \\
\hline TOTAL (\$) & 840 & 860 \\
\hline
\end{tabular}

The installation cost of steel poles is less than that of timber poles due to reduced weight and factory pre-drilled holes (Lacoursiere, 1999; Shaw \& Snyder, 2001). According to Padavick (2006), the cost of installation of steel poles is 50 to 73 percent less than that of timber poles. The cost of installation of steel poles is therefore taken as half of that of timber poles as seen in the table above.

\subsection{Replacement Cost}

Replacement of existing poles can occur due to two reasons:

(i) Failure of the pole due to hurricane winds: here, the total replacement cost is calculated by multiplying the replacement cost of one pole with the number of poles that fail at any given year. This cost is converted to its present value by dividing by the discounted factor.

(ii) Strength deterioration: some utility companies have an inspection program to determine the residual strength remaining in their distribution poles (Mankowski et al., 2002). When the strength of a pole falls below a certain value, it is replaced. Replacement due to strength deterioration is however not considered in this research. 
The replacement cost includes cost of removal and disposal of failed poles, cost of a new pole, and cost of installation of the new pole. These costs are given in Table 4.2 for timber and steel poles.

Table 4.2: Replacement cost of timber and steel poles

\begin{tabular}{|l|c|c|}
\hline \multirow{2}{*}{ Costs } & \multicolumn{2}{|c|}{ Pole Type } \\
\cline { 2 - 3 } & Timber Pole (Class 4 SP) & Steel Pole \\
\hline Removal and disposal (\$) & 595 & 520 \\
\hline $\begin{array}{l}\text { Purchase, shipping \& } \\
\text { handling (\$) }\end{array}$ & 320 & 600 \\
\hline Installation (\$) & 520 & 260 \\
\hline TOTAL (\$) & 1435 & 1380 \\
\hline
\end{tabular}

The removal plus disposal cost of the steel pole is usually lower than that of the timber pole due to its salvage value (Lacoursiere, 1999). Due to lack of data however, the salvage value of the steel poles is not considered. It is however assumed that the steel poles will be recycled rather than disposed. Therefore, the disposal cost of $\$ 75$ per pole used for the timber poles is not used for the steel poles.

It should be noted that replacement due to other damage like woodpecker attack, vehicle collision, and so on is not considered.

\subsection{Maintenance Cost}

Maintenance cost is the cost of remedial maintenance performed on poles showing signs of decay so as to slow down decay over the years. In a survey of utility companies carried out by Mankowski et al. (2002), many of the utilities reported having inspection program 
for their transmission poles but not distribution poles. The 13,940 poles surveyed by Yuan Li et al. (2005) also only had treatment during initial installation but did not undergo any remedial treatment during their use.

Even if remedial treatments are employed, different utilities have different methods and use different chemicals for these treatments. It is also difficult to assess the extent to which these treatments will slow down the deterioration process and for how long. Due to these constraints, remedial maintenance cost is not considered in this analysis. It is assumed that once the poles start deteriorating, it continues until they fail.

\subsection{Hurricane Wind Load}

To carry out the life-cycle cost analysis, the poles are assumed to be located first in Iowa and then in a coastal area at the southern end of Florida where all categories of hurricane can occur. The annual probabilities of failure of the poles at each year is calculated using the equation proposed by Yue Li and Ellingwood (2006) and discussed in Section 3.5.2.

Using the annual probability of failure takes into account all hurricane possibilities by convolving the fragility of the poles and the distribution of wind speed in any year which is modeled by the Weibull distribution.

\subsection{Discount Rate}

A discount rate is needed to calculate the present value of costs that will occur in the future. FEMA 227 (1992) recommended a discount rate between 3 to 4\% for public sector considerations and 4 to $6 \%$ for private sector when performing cost-benefit analysis for seismic rehabilitation of buildings. In this research, a discount rate of $5 \%$ will be used. 


\subsection{Results}

The present value of the life-cycle costs for timber and steel poles located in both Iowa and Florida are presented in Table 4.3 and plotted in Figures 4.1 and 4.2 below. The results show that when the conditional probability of decay (CPD) of the timber poles is considered, the steel poles have a slightly higher life-cycle cost than the timber poles. The cost of the steel poles is about $\$ 2.9$ million and $\$ 4.9$ million higher than the timber poles if the poles are located in Iowa and Florida respectively. However, when CPD of the timber poles is not considered, the steel poles are cheaper than the timber poles.

Without data to compute the CPD of the steel poles, the appropriate comparison should really be between the steel poles and timber poles without CPD. If this is done, the saving for using the steel poles is about $\$ 4.5$ million for poles located in Iowa. However, if a coastal area like Florida is considered where poles are susceptible to greater risk of damage due to hurricane winds, the saving in using the steel poles can be very high. In this case, it is calculated as about $\$ 37$ million over the period of 60 years considered.

One of the reasons for savings using the steel poles is due to its lower installation cost which is as a result of being lighter than timber poles which lower equipment and handling cost as well as factory pre-drilling of holes which lowers labor costs. If the salvage value of the steel poles is considered, the savings are expected to increase.

Table 4.3: Present value of life-cycle cost (US\$)

\begin{tabular}{|l|c|c|c|}
\hline \multirow{2}{*}{ Pole Location } & \multicolumn{3}{|c|}{ Pole Types } \\
\cline { 2 - 4 } & Timber with CPD & Timber w/o CPD & Steel \\
\hline Iowa & $86,172,257$ & $93,535,887$ & $89,035,987$ \\
\hline Florida & $158,243,463$ & $199,971,287$ & $163,132,183$ \\
\hline
\end{tabular}




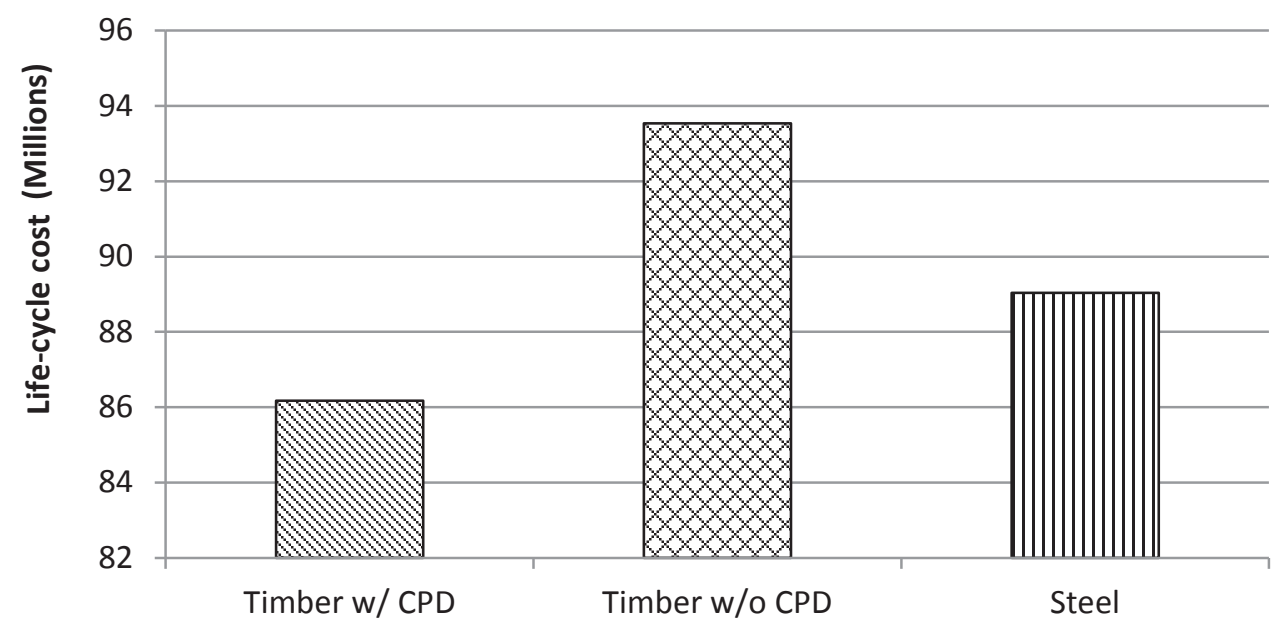

Figure 4.1: Present value of life-cycle cost for poles located in Iowa

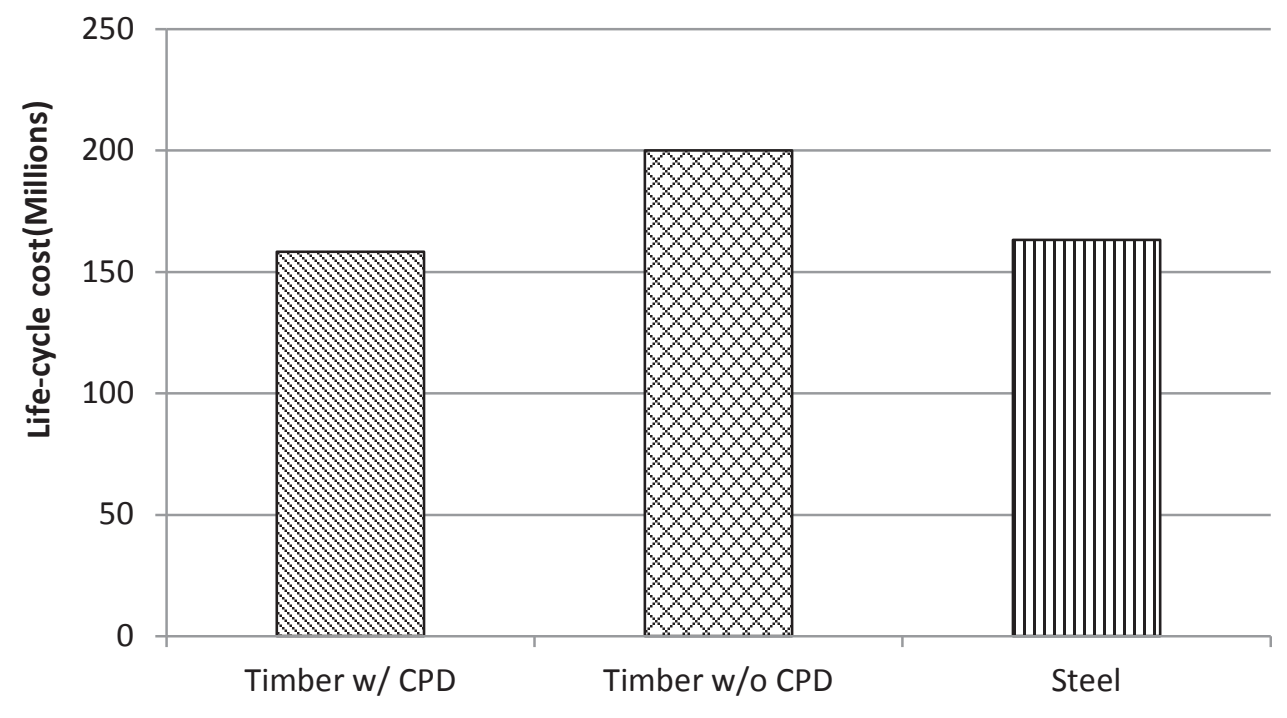

Figure 4.2: Present value of life-cycle cost for poles located in Florida

Lastly, the cumulative life-cycle costs over time are calculated and plotted in Figures 4.3 and 4.4 for poles located in Iowa and Florida respectively. In Figure 22, it can be seen that for the steel and timber poles considering CPD, the rate of increase of the costs over time is small and steady. However, when CPD is not considered for the timber poles, the 
costs rise significantly after about 40 years as deterioration takes its toll thereby drastically increasing the probability of failure of the poles given a certain wind speed.

For poles located in Florida, the life-cycle cost over time of the steel and timber poles considering CPD are very similar throughout the period of 60 years considered. When CPD is not considered however, the timber poles have much higher life-cycle cost and the gap increases with time. Unlike poles located in Iowa however, the rate of increase of the life-cycle costs appears to slow down with time. This can be attributed to the difference in parameters of the Weibull distribution of wind speeds in the two locations.

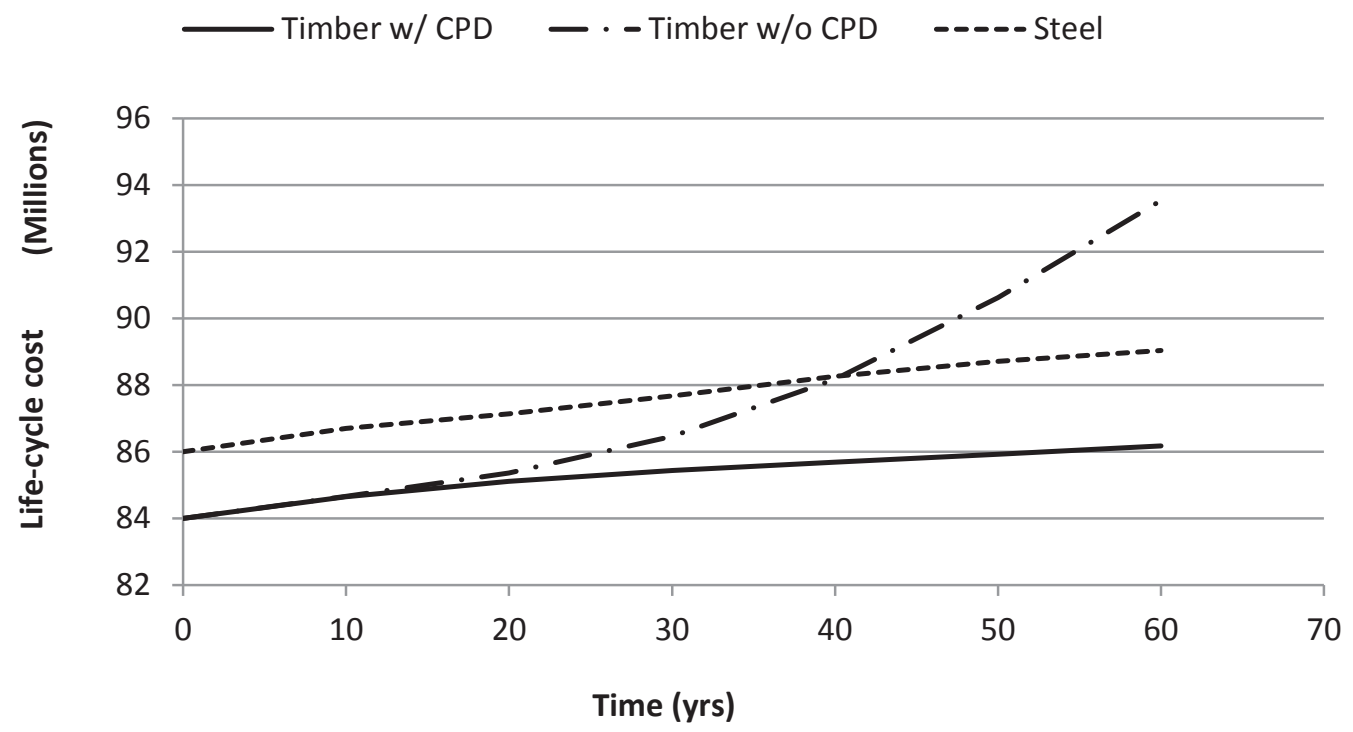

Figure 4.3: Cumulative life-cycle costs over time for poles in Iowa 


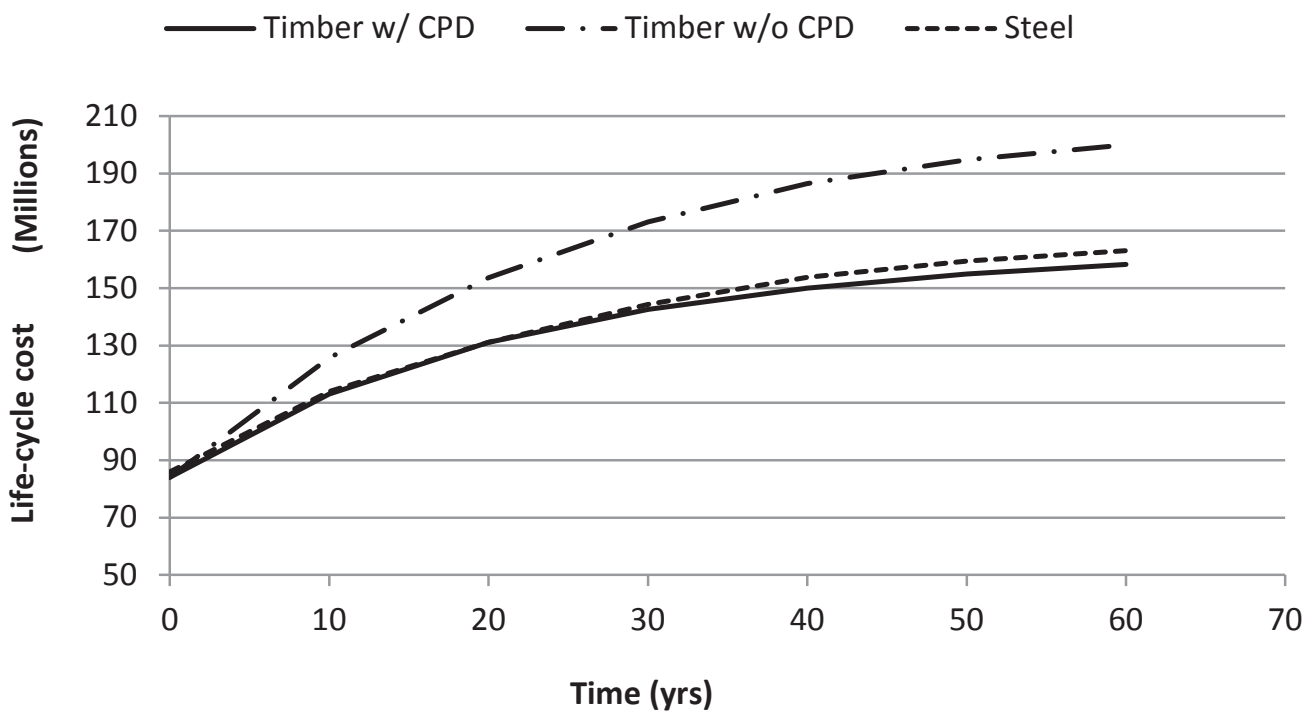

Figure 4.4: Cumulative life-cycle costs over time for poles in Florida 


\section{CHAPTER 5 \\ FUTURE WORK RECOMMENDATIONS}

The following are some recommendations for future research to help improve understanding of the reliability of power distribution systems:

$>$ The proposed framework considers the reliability of single poles. However, failure of one pole can cause cascading failure of a distribution line. Therefore, a wider reliability analysis which considers the whole support system by means of inter-dependent probabilities of failure of the poles can be investigated.

$>$ Failure of poles causes disruption of electricity supply to customers. A more comprehensive life-cycle cost analysis that considers cost of disruption can therefore be carried out. This requires actual data from utility companies.

$>$ Fragility and life-cycle cost analysis considering pole replacement due to strength deterioration as well as considering periodic maintenance of the poles can be carried out if data from a utility company is available. 


\section{CHAPTER 6 \\ CONCLUSIONS}

A framework is proposed for comparing age-dependent structural reliability and lifecycle cost of power distribution poles made with different materials and subjected to natural hazards. To illustrate the framework, fragility and life-cycle cost analyses were performed on steel and timber distribution poles subjected to strong wind load such as that experienced during hurricanes. Based on the results, the following conclusions can be drawn:

$>$ Steel distribution poles have similar or better structural reliability compared to timber poles. With age, the rate of decrease in strength due to deterioration is higher for timber poles compared to steel poles. This means steel poles are more reliable over time.

$>$ If conditional probability of decay is not considered, i.e., if both poles are assumed to start deteriorating once the initial protective coating is exhausted, steel distribution poles have lower life-cycle cost compared to timber poles even though the initial cost of purchase of the steel poles is higher. This is largely due to higher reliability and lower installation cost of the steel poles.

Based on the above points, steel poles have the potential to replace timber poles in power distribution systems.

Due to several site and material specific factors that affect deterioration, actual data collected from the field should be used for more accurate results that can aid in decision making by utility companies. 


\section{CHAPTER 7}

\section{REFERENCES}

AGA. (2011). Service Life of Galvanized Steel Articles in Soil Applications. Retrieved $02 / 18 / 2014$, 2014 ,

from http://www.galvanizeit.org/images/uploads/publicationPDFs/Galvanized_Steel_Performa nce_in_Soil.pdf

ANSI-O5.1. (2002). Timber Poles Specifications and Dimensions.

AS/NZS-2041. (1998). Standard for Buried Corrugated Metal Structures (pp. 67-71).

ASCE-72. (1990). Design of Transmission Pole Structures. New York.

ASCE-74. (1991). Guidelines for Electrical Transmission Line Structural Loading. Reston, VA.

ASCE-111. (2006). Reliability-Based Design of Utility Pole Structures.

ASTM-A123. (2013). Standard Specification for Zinc (Hot-Dip Galvanized) Coatings on Iron and Steel Products.

Bjarnadottir, S., Li, Y., \& Stewart, M. G. (2013a). Hurricane risk assessment of power distribution poles considering impacts of a changing climate. Journal of Infrastructure Systems, 19(1), 12-24. doi: 10.1061/(ASCE)IS.1943-555X.0000108

Bjarnadottir, S., Li, Y., \& Stewart, M. G. (2013b). Risk-based economic assessment of mitigation strategies for power distribution poles subjected to hurricanes. doi: $10.1080 / 15732479.2012 .759240$

Blake, E. S., Kimberlain, T. B., Berg, R. J., Cangialosi, J. P., \& II, J. L. B. (2013). Tropical Cyclone Report - Hurricane Sandy. (AL182012). 
Bolin, C. A., \& Smith, S. T. (2011). Life cycle assessment of pentachlorophenol-treated wooden utility poles with comparisons to steel and concrete utility poles. Renewable and Sustainable Energy Reviews, 15(5), 2475-2486. doi: 10.1016/j.rser.2011.01.019

Brown, R. E. (2008). Electric power distribution reliability: CRC press.

Butera, R. (2000). Asset management for the distribution pole plant-closing the performance gap between traditional maintenance and asset management. Paper presented at the Proceedings of the 2000 Power Engineering Society Summer Meeting, July 16, 2000 - July 20, 2000, Seattle, WA, United states.

Darbin, M., Jailloux, J., Montuelle, J., \& Romanoff. (1988). Durability of Reinforced Earth Structures: The Results of A Long-Term Study Conducted on Galvanized Steel. $\begin{array}{llll}\text { ICE } & \text { Proceedings, } & \text { 84, }\end{array}$ http://www.icevirtuallibrary.com/content/article/10.1680/iicep.1988.508

Davidson, R. A., Liu, H., Sarpong, K., Sparks, P., \& Rosowsky, D. V. (2003). Electric power distribution system performance in Carolina Hurricanes. Natural Hazards Review, 4(1), 36-45. doi: 10.1061/(ASCE)1527-6988(2003)4:1(36)

Ellingwood, B. R., \& Tekie, P. B. (1999). Wind load statistics for probability-based structural design. Journal of Structural Engineering, 125(4), 453-463.

Foedinger, R., Boozer, J. F., Bronstad, M. E., \& Davidson, J. W. (2003). Development of energy-absorbing composite utility pole. Transportation Research Record: Journal of the Transportation Research Board, 1851(1), 149-157.

Foschi, R. O. (2004). Reliability theory and applications to risk analysis of power components and systems. International Journal of Electrical Power \& Energy Systems, 26(4), 249-256. doi: http://dx.doi.org/10.1016/i.ijepes.2003.10.004

George, R., \& Stetson, L. E. (1999, 1999). Application experience with $69 \mathrm{kV}$ steel utility poles. Paper presented at the Rural Electric Power Conference, 1999. 
Guikema, S. D., Quiring, S. M., \& Han, S.-R. (2010). Prestorm Estimation of Hurricane Damage to Electric Power Distribution Systems. Risk Analysis, 30(12), 1744-1752. doi: 10.1111/j.1539-6924.2010.01510.x

Gustavsen, B., \& Rolfseng, L. (2000). Simulation of wood pole replacement rate and its application to life cycle economy studies. IEEE Transactions on Power Delivery, 15(1), 300-306. doi: 10.1109/61.847266

Han, S.-R., Rosowsky, D., \& Guikema, S. (2013). Integrating Models and Data to Estimate the Structural Reliability of Utility Poles During Hurricanes. doi: 10.1111/risa.12102

Hines, P., Apt, J., \& Talukdar, S. (2009). Large blackouts in North America: Historical trends and policy implications. Energy Policy, 37(12), 5249-5259.

Lacoursiere, B. (1999, 1999). Steel utility poles: advantages and applications. Paper presented at the Rural Electric Power Conference, 1999.

Li, H., Zhang, J., \& Bhuyan, G. (2006). Reliability Assessment of Electrical Overhead Distribution Timber Poles, Probability Methods Applied to Power Systems. Paper presented at the International Conference, Stockholm.

Li, X. H. (2004). Life Cycle Cost of Support Poles in Distribution Lines: McGill University.

Li, Y., \& Ellingwood, B. R. (2006). Hurricane damage to residential construction in the US: Importance of uncertainty modeling in risk assessment. Engineering Structures, 28(7), 1009-1018. doi: 10.1016/j.engstruct.2005.11.005

Li, Y., Yeddanapudi, S., McCalley, J. D., Chowdhury, A. A., \& Moorehead, M. (2005, 23-25 Oct. 2005). Degradation-path model for wood pole asset management. Paper presented at the Proceedings of the 37th Annual North American Power Symposium, 2005. . 
Mankowski, M., Hansen, E., \& Morrell, J. (2002). Wood pole purchasing, inspection, and maintenance: A survey of utility practices. Forest Products Journal, 52(11/12), 43-50.

Miller, G. A., Fenton, T. E., Oneal, B. R., Tiffany, B. J., \& Burras, C. L. (2010). Iowa Soil Properties and Interpretations Database.

Morrell, J. J. (2008). Estimated service life of wood poles. Technical Bulletin, North American Wood Pole Council, $\underline{\text { http://www. }}$ woodpoles. org/documents/TechBulletin_EstimatedServiceLifeofWoodPole_12-08. pdf (Last accessed 5 April 2013).

Nelson, R. F. (1999, October 21-22). Managing the aging timber poles system: case study assessment projects and methods to enhance the useful life of the timber pole system. Paper presented at the Proc. of the timber pole conf., Reno, NV.

NESC. (2002). IEEE Standard. Piscataway, New Jersey.

NWS. (2001). Hurricanes--: Unleashing Nature's Fury: a Preparedness Guide (Vol. 94050): US Department of Commerce, National Oceanic and Atmospheric Administration, National Weather Service.

Ostendorp, M. (2003). Ground line corrosion damage activity and damage assessment for direct embedded steel structures and guy anchors. Paper presented at the ESMO 2003 Proceedings; The Power is in Your Hands, April 6, 2003 - April 10, 2003, Orlando, FL, United states.

Ouyang, M., \& Dueñas-Osorio, L. (2014). Multi-dimensional hurricane resilience assessment of electric power systems. Structural Safety, 48(0), 15-24. doi: http://dx.doi.org/10.1016/j.strusafe.2014.01.001

Padavick, J. (2006, 15-19 Oct. 2006). Austin Energy Builds Stronger Distribution System , Cost Effectively, with Steel Poles. Paper presented at the Transmission \& Distribution 
Construction, Operation and Live-Line Maintenance, 2006. ESMO 2006. IEEE 11th International Conference on.

Robinson, J. (2005). Predicting the in-ground performance of galvanized steel.

Romanoff, M. (1957). Underground corrosion: US Government Printing Office.

Russell, L. R., \& Schueller, G. I. (1974). Probabilistic Models for Texas Gulf Coast Hurricane Occurrences. JPT, Journal of Petroleum Technology, 26, 279-288.

Shafieezadeh, A., Onyewuchi, U. P., Begovic, M. M., \& DesRoches, R. (2014). AgeDependent Fragility Models of Utility Wood Poles in Power Distribution Networks Against Extreme Wind Hazards. Power Delivery, IEEE Transactions on, 29(1), 131-139. doi: 10.1109/TPWRD.2013.2281265

Shaw, M., \& Snyder, D. E. (2001). Selection of wood pole alternatives by means of present-worth analysis. Paper presented at the 45th IEEE Rural Electric Power Conference, April 29, 2001 - May 1, 2001, Little Rock, AR, United states.

Short, T. A. (2006). Electric Power Distribution Equipment and Systems. Boca Raton, FL: CRC Press.

Stewart, A. H., \& Goodman, J. R. (1990). Life cycle economics of wood pole utility structures. Power Delivery, IEEE Transactions on, 5(2), 1040-1046. doi: $10.1109 / 61.53119$

Stewart, A. J. (1996, March 25-27). Utility poles: how long do they last. Paper presented at the Proceeding of the Conference on Poles and Piles, Fort Collins, CO.

U.S. Congress, O. o. T. A. (1990). Office of Technology Assessment. Physical vulnerability of electric system to natural disasters and sabotage: OTA-E-453, Washington, DC: US Government Printing Office. 
Vickery, P., Skerlj, P., \& Twisdale, L. (2000). Simulation of Hurricane Risk in the U.S. Using Empirical Track Model. Journal of Structural Engineering, 126(10), 1222-1237. doi: doi:10.1061/(ASCE)0733-9445(2000)126:10(1222)

Wang, C.-h., \& Leicester, R. H. (2008). Decay in Ground. In F. a. W. P. Australia (Ed.).

Wen, Y., \& Kang, Y. (2001). Minimum Building Life-Cycle Cost Design Criteria. I: Methodology. Journal of Structural Engineering, 127(3), 330-337. doi: doi:10.1061/(ASCE)0733-9445(2001)127:3(330)

Willis, H. L., \& Philipson, L. (2005). Understanding electric utilities and de-regulation (Vol. 27): CRC Press.

Wolfe, R., \& Moody, R. (1997). Standard specifications for wood poles. Paper presented at the Utility Pole Structures Conf and Trade Show; Nov. 6-7, 1997; Reno/Sparks, Nevada.

Yao, J. T. P., \& Kawamura, H. (2001). On Structural Reliability. Journal of Temporal Design in Architecture and the Environment, 1(1), 1-5.

Zamanzadeh, M., Kempkes, C. D., Aichinger, D., \& Riley, D. (2006). Laboratory and field corrosion investigation of galvanized utility poles. Paper presented at the 2006 Electrical Transmission Conference, October 15, 2006 - October 19, 2006, Birmingham, AL, United states.

Zhang, X., \& Gockenbach, E. (2007). Component Reliability Modeling of Distribution Systems Based on the Evaluation of Failure Statistics. Dielectrics and Electrical Insulation, IEEE Transactions on, 14(5), 1183-1191. doi: 10.1109/TDEI.2007.4339478 